\title{
Design of Outer Membrane Vesicles as Cancer Vaccines: A New Toolkit for Cancer Therapy
}

\author{
Yingxuan Zhang ${ }^{1,+}$, Zheyan Fang ${ }^{1,+}$, Ruizhen $\mathrm{Li}^{1}{ }^{1}$, Xiaotian Huang ${ }^{1,2}$ and Qiong Liu ${ }^{1,2, *(\mathbb{C})}$ \\ 1 Department of Medical Microbiology, School of Medicine, Nanchang University, Nanchang 330006, China \\ 2 Key Laboratory of Tumor Pathogenesis and Molecular Pathology, School of Medicine, Nanchang University, \\ Nanchang 330006, China \\ * Correspondence: p19890528@126.com; Tel.: +86-1369-955-5282 \\ + Both authors equally contributed to this review.
}

Received: 9 July 2019; Accepted: 2 September 2019; Published: 6 September 2019

\begin{abstract}
Cancer vaccines have been extensively studied in recent years and have contributed to exceptional achievements in cancer treatment. They are some of the most newly developed vaccines, although only two are currently approved for use, Provenge and Talimogene laherparepvec (T-VEC). Despite the approval of these two vaccines, most vaccines have been terminated at the clinical trial stage, which indicates that although they are effective in theory, concerns still exist, including low antigenicity of targeting antigens and tumor heterogeneity. In recent years, with new understanding of the biological function and vaccine potential of outer membrane vesicles (OMVs), their potential application in cancer vaccine design deserves our attention. Therefore, this review focuses on the mechanisms, advantages, and prospects of OMVs as antigen-carrier vaccines in cancer vaccine development. We believe that OMV-based vaccines present a safe and effective cancer therapeutic option with broad application prospects.
\end{abstract}

Keywords: cancer vaccines; outer membrane vesicles; antigen carrier; therapy

\section{Introduction}

Cancer is the leading cause of death in economically developed countries and the second leading cause of death in developing countries [1]. Global cancer statistics estimated 18.1 million new cancer cases and 9.6 million cancer deaths in 2018 [2]. For more than 100 years, the hallmark of medical treatment for cancer has been intravenous cytotoxic chemotherapy. New and advanced approaches to cancer research have led to the development of a variety of cancer vaccines in quick succession, and numerous vaccine strategies are currently being evaluated, both pre-clinically and clinically $[3,4]$. Although traditional cytotoxic chemotherapy remains a treatment backbone for many malignancies, vaccines are now a component of treatment for many types of cancer, including breast, colorectal, lung, and pancreatic cancers; lymphoma; leukemia; and multiple myeloma in preclinical studies, and some are even undergoing clinical trials [4-7]. However, owing to the characteristics of cancer cells, there are many difficulties in the development of cancer vaccines. The only cancer vaccines currently in routine clinical use are the prostate cancer vaccine Sipuleucel-T (Provenge) and Talimogene laherparepvec (T-VEC) used for the treatment of advanced melanoma; the development of many new vaccines is ongoing with Phase II/III clinical trials [8-11]. Cancer cells are different from bacteria and viruses in that they are derived from normal cells and exhibit many similarities to somatic cells. Finding a highly efficient vector that allows cancer antigens to activate the immune system and kill or inhibit cancer cell proliferation at this stage is the key to the development of cancer vaccines.

Among the many carriers evaluated for their presentation of cancer antigens, extracellular vesicles (EVs), produced by spontaneous vacuolation of the bacterial membrane, have attracted increasing 
attention in the research field. Like mammalian cells, Gram-negative and Gram-positive bacteria release nano-sized membrane vesicles into the extracellular environment [12,13]. In recent decades, research into EVs from Gram-negative bacteria has increased substantially, but there is little to no EV-related research with Gram-positive bacteria, because of the inference caused by the thick cell wall of Gram-positive bacteria [14,15]. EVs from Gram-negative bacteria originate from the outer membrane and are thus usually referred to as outer membrane vesicles (OMVs) [16]. OMVs are lipid-based vesicular nanostructures that contain a variety of porins and can carry heterologous substances to accomplish the adjuvant and delivery functions [17]. Owing to their capacity to flexibly transport delivered antigens to endothelial cells or antigen presenting cells (APCs), OMVs have great potential in vaccine development [18-20]. Although a few studies have reported the antitumor effect of EVs from Gram-positive bacteria, their formation mechanism and biological function have not been fully elucidated. Therefore, in this review, we mainly focus on OMVs as the EVs from Gram-negative bacteria and analyze the status of cancer vaccine research and the advantages of OMVs as a carrier, focusing on the requirements for designing OMVs as antigen carriers for cancer treatment.

\section{Vaccines in Cancer Therapy}

\subsection{Historical Overview}

A cancer vaccine either prevents infections with cancer causing viruses, treats existing cancer, or prevents the development of cancer in certain high-risk individuals [3,6,21]. Vaccination against an infectious neoplastic agent can be categorized based on three clinical applications: (1) a prophylactic vaccine to prevent infection or acute disease; (2) a therapeutic vaccine to treat an established infection before a malignancy has been induced; or (3) a therapeutic vaccine to treat the infection after the malignant tumor has developed. Prophylactic vaccines are mainly used in viral infections associated with a high risk of cancer, for example, the human papillomavirus (HPV) vaccine [22]. Prophylactic vaccines therefore seem to be an ideal approach to limit the risk of cancer; however, it is difficult to conduct prophylactic trials as the response to the vaccine cannot be evaluated within a short period of time, when compared with suppression of infection or disease in therapeutic vaccine trials [23]. Advances in targeted therapies have reinvigorated interest in cancer immunotherapy because (1) therapeutic vaccines employed as a monotherapy could deliver a targeted immune-mediated effect in tumors, and (2) the advantage of cancer vaccines in comparison with passive immunotherapy is that T-cell driven responses and associated memory may assist during disease recurrence [24]. Since our immune system is built to target and destroy "non-self," theoretically, cancer vaccination is the safest, most natural, and effective therapeutic approach against cancer. Owing to their ability of immune regulation and presenting multiple heterologous antigens to host cells, OMVs can be a new option for design as an effective therapeutic vaccine to deliver tumor antigens or small molecule drugs to APCs or even targeted cancer cells through genetic engineering.

To date, a group of cancer vaccine models have been developed, including whole-cell and lysed-cell vaccines, gene-modified tumor vaccines, heat shock proteins, peptide-based vaccines, naked DNA, viral vectors, and ex vivo dendritic cell (DC) vaccines [21,25-27]. These vaccine models present a good example for the theory that "prevention is better than cure". Their advancement and application will ensure a decrease in cancer incidence globally. At present, the promotion of cancer vaccines in clinical practice is positive, and in general, acceptance of these vaccines is positive. Issues still to be addressed are design of effective cancer vaccines, lack of familiarity with cancer vaccine models, varied beliefs regarding the risk of acquiring infections, and concerns regarding age specifications for the vaccines $[3,28,29]$. Our focus is on improving the protective effect of the vaccine stimulating to the host and the delivery efficiency of the vaccine vector. Moreover, we believe that OMVs as a tumor antigen carrier can provide us with a novel strategy to design cancer vaccines. 


\subsection{Status of Clinical Trials}

A large number of preclinical and clinical studies involving cancer vaccines with varying levels of success have been described over the last two decades. However, with the exception of Sipleucel $\mathrm{T}$, an ex vivo DC vaccine for prostate cancer, and T-VEC, an injectable modified herpes virus for advanced melanoma, no therapeutic cancer vaccine has yet shown clinical efficacy in phase III randomized trials, mainly because of the type of patients recruited in the various clinical studies and reasons including the trial design, the specific vaccination approach, and host-related factors [30-32]. Rindopepimut (CDX-110) is a peptide vaccine that targets epidermal growth factor receptor variant III (EGFRvIII) to cure glioblastoma. It showed clinical benefit and significant efficacy in phase II clinical trials; however, phase III trials were terminated as it was deemed likely the study would fail to meet its primary end point $[33,34]$. Additionally, this antigen was mixed with granulocyte-macrophage colony-stimulating factor (GM-CSF) and used to vaccinate patients with breast cancer in the exploratory phase I-II trials [35].

Unfortunately, the results from clinical settings so far have been disappointing. In a cumulative analysis of several vaccine trials including 936 patients with different types of solid tumors, Klebanoff et al. used response rate as a measure of positive outcome and concluded that only $3.6 \%$ of patients had an objective benefit from vaccination [36]. However, disappointing, lessons learned from recent studies associated with the immune-suppressive microenvironment of tumor cells have suggested further strategies for improvement [37,38]. Indeed, the clinical success of checkpoint blockades has underscored the role of peripheral tolerance mechanisms in limiting vaccine responses and highlighted the potential for applying combination therapies [39]. In conclusion, the future of cancer vaccines looks bright; however, there remain important problems to be addressed as follows: (1) there is still a need for sufficient quantity of tumor cell antigens; and (2) lasting and effective immune responses are not induced. Furthermore, the knowledge of immune-editing and immune-suppressive mechanisms that operate in each individual patient with cancer is gaining attention in the efforts to design new cancer vaccines.

\section{New OMV Applications: Tumor Vaccines}

\subsection{Roles of $O M V$ s as Vaccines}

OMVs are naturally released by Gram-negative bacteria; they mainly comprise the outer membrane $(\mathrm{OM})$ and periplasmic components [16]. The OM comprises inner and outer phospholipids (PL) and lipopolysaccharide (LPS), combined with interspersed membrane proteins. The lumen of the vesicle may contain a variety of bacterial compounds from the periplasm or cytoplasm, such as proteins, RNA or DNA, and peptidoglycan, which can each act as or encode antigens. The formation of OMVs involves three steps: (1) breakage of connections between OM and peptidoglycan, (2) accumulation of components in the periplasmic space, and (3) activity of specific signal and effector molecules [40]. These processes of OMV formation determine the critical role played by OMVs in the interaction between pathogen and host [41].

Since the discovery that OMVs can induce an immune response, many studies have aimed to examine the potential for immunization with OMV components. Toxins can act as adhesins for OMVs and therefore allow vesicles to enter cells using the receptor-mediated endocytic pathway [41]. Common components of vesicles, such as outer membrane protein A (OmpA), could also contribute to host cell entry; this adhesin fully activated macrophage cytokine production when presented in the OMV membrane rather than as a mixture of purified vesicle components [41]. OMVs have proper size (20-200 nm), which is an important factor for their efficient processing by APCs, and can present a range of surface antigens in a native conformation, enabling their entry into lymph vessels and uptake by APCs [42]. The natural properties of OMVs, such as their immunogenicity, capacity to act as self-adjuvants, and potential for uptake by immune cells also make them attractive for application as vaccines against pathogenic bacteria [40]. To date, the first generation of OMV vaccines, 
Bexsero (Novartis) has been approved for the market against serogroup B Neisseria meningitidis [43]. Other OMV-based vaccines, though not yet in clinical trial stage, are still being developed in preclinical studies. Additionally, a variety of applications in OMV research and development have been proposed with a focus on infectious diseases (pneumonia, meningitis, and whooping cough) and specifically enteric diseases (cholera, salmonellosis, and shigellosis), most of which utilize OMV antigen binding (Table 1) [44-48].

Furthermore, OMVs exhibit a number of functions that aid bacteria in the process of infecting host cells [16]. The most remarkable example is the use of vesicles as a delivery system for pathogen-associated molecular patterns (PAMPs) [49]. OMVs laden with PAMPs, and other OM components that can affect the course of infection and associated host responses are then delivered into distant host cells. The immunogenic properties of OMVs lead to protective mucosal and systemic bactericidal antibody responses that have been exploited for vaccine purposes. Several studies have also documented B-cell responses to OMVs from various bacteria, such as Escherichia coli (E. coli), Salmonella typhimurium, and Acinetobacter baumannii indicating that OMVs can easily be used as antigen delivery systems to generate effective antibody responses [50-53]. Indeed, there is a growing interest in the use of OMVs as a delivery system of tumor antigens for the design of cancer vaccines. 
Table 1. Outer membrane vesicle-based vaccine against infection in preclinical test.

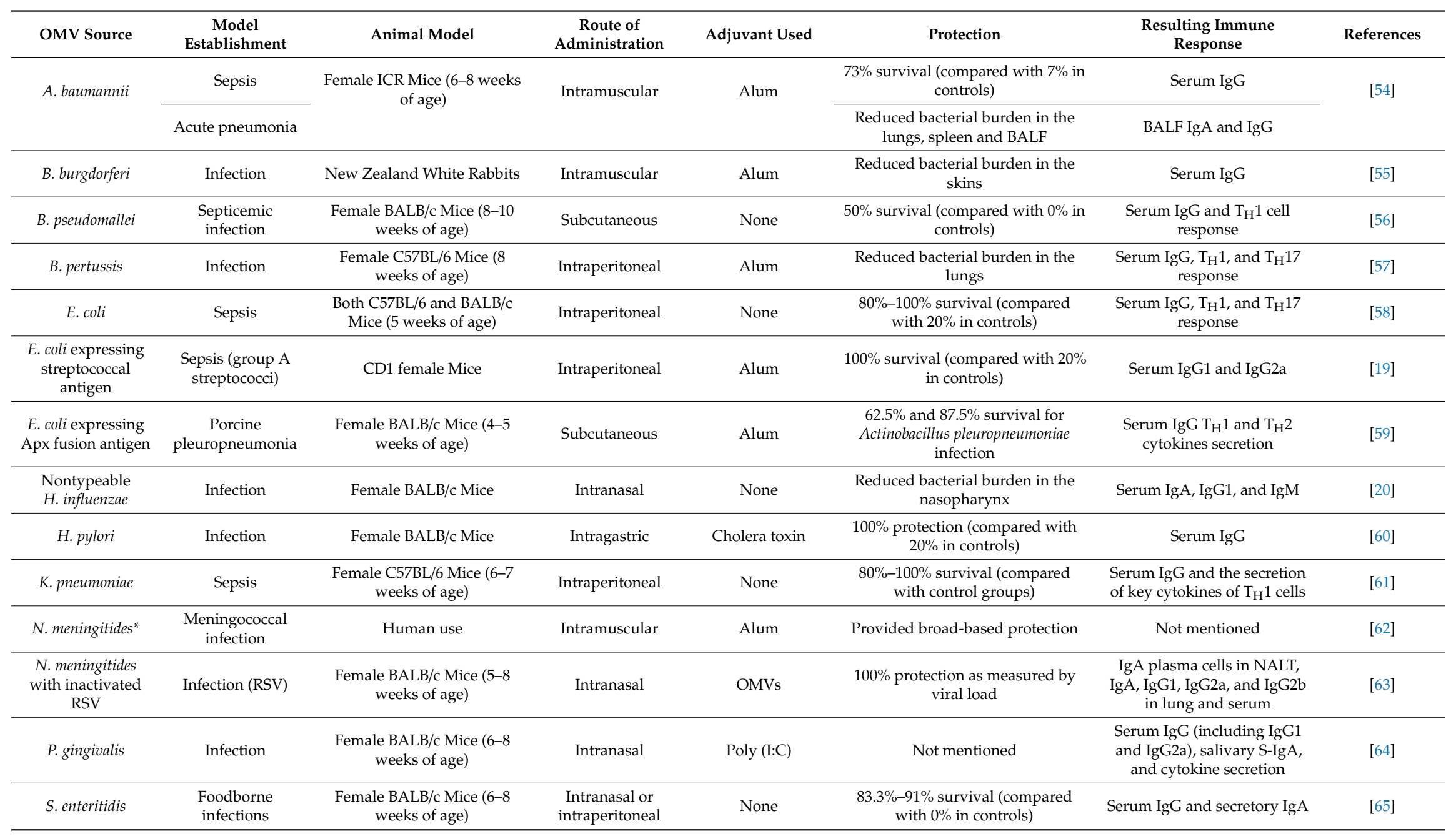


Table 1. Cont.

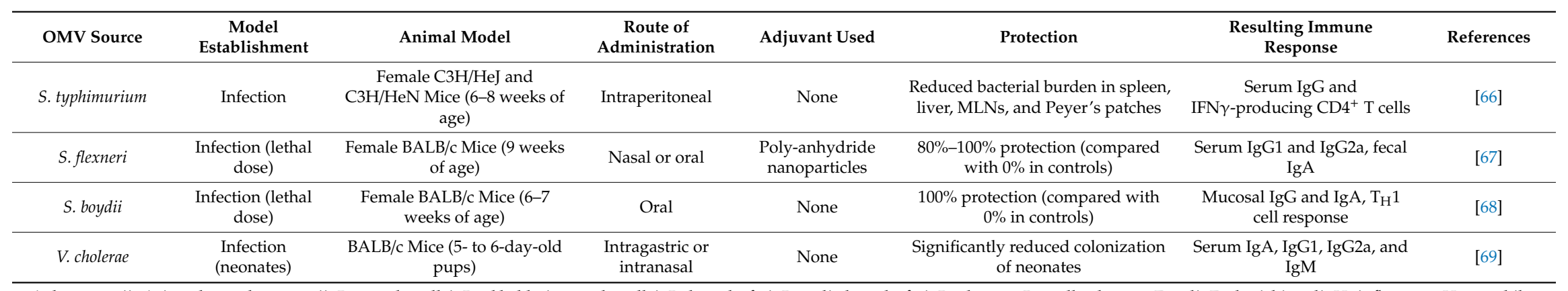

A. baumannii, Acinetobacter baumannii; B. pseudomallei, Burkholderia pseudomallei; B. burgdorferi, Borrelia burgdorferi; B. abortus, Brucella abortus; E. coli, Escherichia coli; H. influenzae, Haemophilus influenzae; H. pylori, Helicobacter pylori; K. pneumoniae, Klebsiella pneumoniae; N. meningitidis, Neisseria meningitidis; P. gingivalis, Porphyromonas gingivalis; S. enteritidis, Salmonella enteritidis; S. typhimurium, Salmonella typhimurium; S. flexneri, Shigella flexneri; S. boydii, Shigella boydii; V. cholerae, Vibrio cholerae; BALF, bronchoalveolar lavage fluid; IFN $\gamma$, interferon- $\gamma$; MLN, mesenteric lymph node; NALT, nasal-associated lymphoid tissue; TH, T helper; RSV, respiratory syncytial virus. *The only OMV vaccine licensed to date. 


\subsection{Mechanisms of OMVs Design as Cancer Vaccines}

OMVs from Gram-negative bacteria are gaining increasing attention as vaccine candidates for their potential use as carriers of heterologous antigens, presenting the potential for highly effective and easy to produce multi-valent vaccines. Since Kesty and Kuehn first demonstrated the incorporation of heterologous expression of OM and periplasmic proteins in bacterial vesicles [18], several studies have used a variety of strategies to construct recombinant OMVs from different bacteria. Some of the most widely used bacteria for constructing functional OMVs are Salmonella and E. coli. Salmonella have been utilized to produce OMVs, which contain pneumococcal surface protein A (PspA) to protect against Streptococcus pneumoniae infection; whereas E. coli OMVs containing recombinant HtrA were used in chlamydia vaccine development, and both these strategies were directing target antigens to the lumen of OMVs $[70,71]$. However, OMVs delivering tumor antigen as cancer vaccines are still in the infancy stage. We aim to explore the preliminary mechanism of OMVs as cancer vaccines for anti-tumor treatment so that more researchers can realize the potential of OMVs as novel cancer vaccines.

The mechanisms involved in the design of recombinant OMVs and underlying the functions of OMVs recombinant with heterologous antigens and pathways through which they gain entry in host cells in vitro have been clarified (Figure 1). The mode of OMV transport to the site of the desired immune response has an important impact on potency. Generally, vaccines are injected subcutaneously or intramuscularly; therefore, transport of antigens through the lymphatic system from the peripheral tissues to the lymphoid organs must be considered in vaccine design. When fluids and serum components circulate between blood capillaries and the interstitial space, peripheral immune cells and antigens or pathogens can enter the lymph vessels. Initial lymph vessels are 10-60 $\mu \mathrm{m}$ in diameter, whereas larger lymphatic vessels can be up to $2 \mathrm{~mm}$ in diameter. Bacteria must be carried into the lymphatic system by specialized cells, such as DCs, which can squeeze through openings between overlapping endothelial cells, whereas OMVs, with the size of 20-200 nm, have an intrinsic advantage in transport efficiency [42]. Furthermore, delivery of an OMV-associated antigen in a sulfatase-dependent manner was recently reported, where OMVs were found to traverse the gut mucosal barrier, accessing the gut epithelial cells and underlying intestinal macrophages in a sulfatase-dependent manner, and thus, triggering intestinal inflammation (Figure 1A) [72].

Furthermore, the uptake mechanism of OMVs should be identified and internalization of OMVs can be achieved by five different pathways: clathrin-, caveolin-, and lipid raft-mediated endocytosis; membrane fusion pathways; and micropinocytosis (Figure 1B) [49]. Clathrin-mediated endocytosis utilizes dynamin for budding off, and endosomal trafficking routes for vesicle entry; its cargo can then either be returned to the cell surface or targeted to lysosomes for degradation [73]. Based on our understanding of virulence factor transport, it is reasonable to infer that OMVs can utilize toxin-receptor interactions to facilitate their cargo delivery via clathrin dependent endocytosis. The size limit for clathrin-mediated endocytosis is $120 \mathrm{~nm}$ (diameter), and therefore, several studies have identified this process as a route for OMV entry, via receptor-ligand binding [74,75]. Since Helicobacter pylori OMVs are known to transport vacuolating toxin VacA, an important cytotoxic virulence factor during infection, they have been shown to facilitate their cargo delivery via clathrin-mediated endocytosis [76]. Caveolin-mediated endocytosis occurs via invagination $(80 \mathrm{~nm})$ of membranes rich in cholesterol, sphingolipids, and caveolin [77]. Sharpe and colleagues identified this process in nontypeable Haemophilus influenzae and showed that OMVs colocalized with the endocytosis protein caveolin, indicating that internalization is mediated by caveolae, which are cholesterol-rich lipid raft domains [78]. Despite sluggish internalization speed (five-times slower than clathrin-mediated), it leads in the efficient delivery of cargo to the cytosol [73]. Lipid rafts are domains of the plasma membrane that are also enriched in sphingolipids and cholesterol [77]. It is hypothesized that clustering of cholesterol-rich regions causes curvature in the membrane, driving movement of molecules into the host cell via invagination $(90 \mathrm{~nm})$. Membrane fusion is another mechanism utilized by OMV for entry into host cells; this does not entirely depend on active, energetic processes and the exact mechanisms involved are still under investigation $[49,79]$. Further, macropinocytosis is characterized by the formation of large 
(over $200 \mathrm{~nm}$ in diameter), actin-driven, ruffled protrusions from the cell membrane [80]. However, macropinocytosis is generally not a cargo-induced process; it allows internalization of endocytic vesicles up to $1 \mu \mathrm{m}$ in diameter; thus, entry via this route is thought not to be a deliberate OMV-driven event [81]. Therefore, the size of the OMV population is relevant when studying endocytic routes, as macropinocytosis allows internalization of vesicles of $1 \mu \mathrm{m}$ diameter, while clathrin-dependent endocytosis allows internalization of particles with a maximum diameter of $120 \mathrm{~nm}$. Different isolation methods can introduce a bias towards particular sizes of OMVs, and therefore the purification method is also one of the most important considerations in the design of OMV vaccines.

A

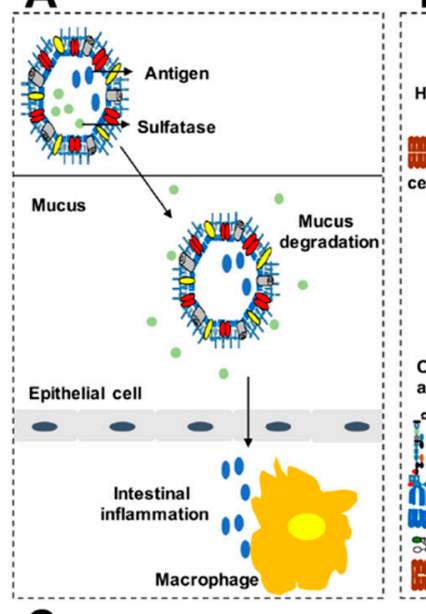

B

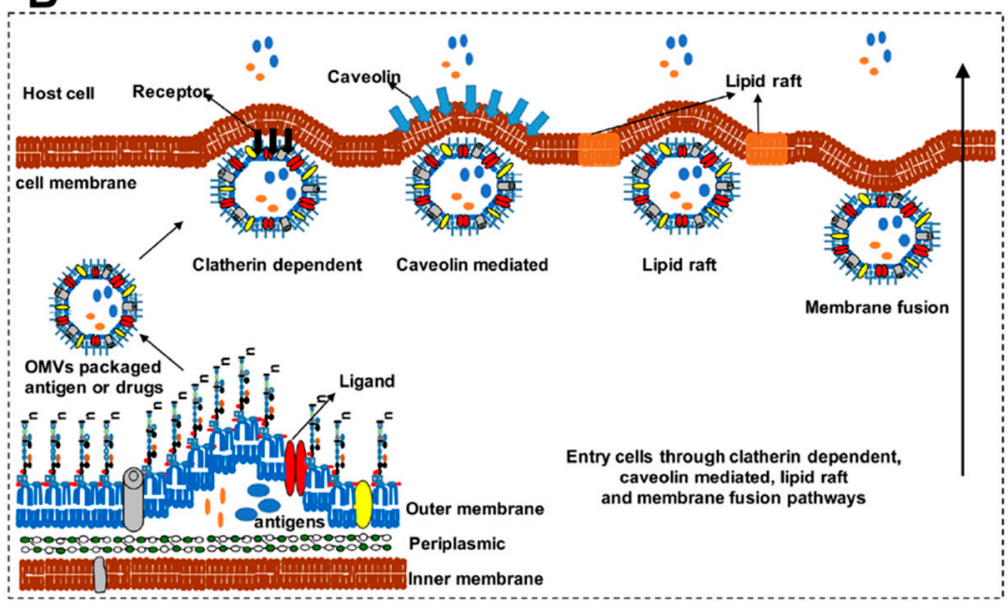

C

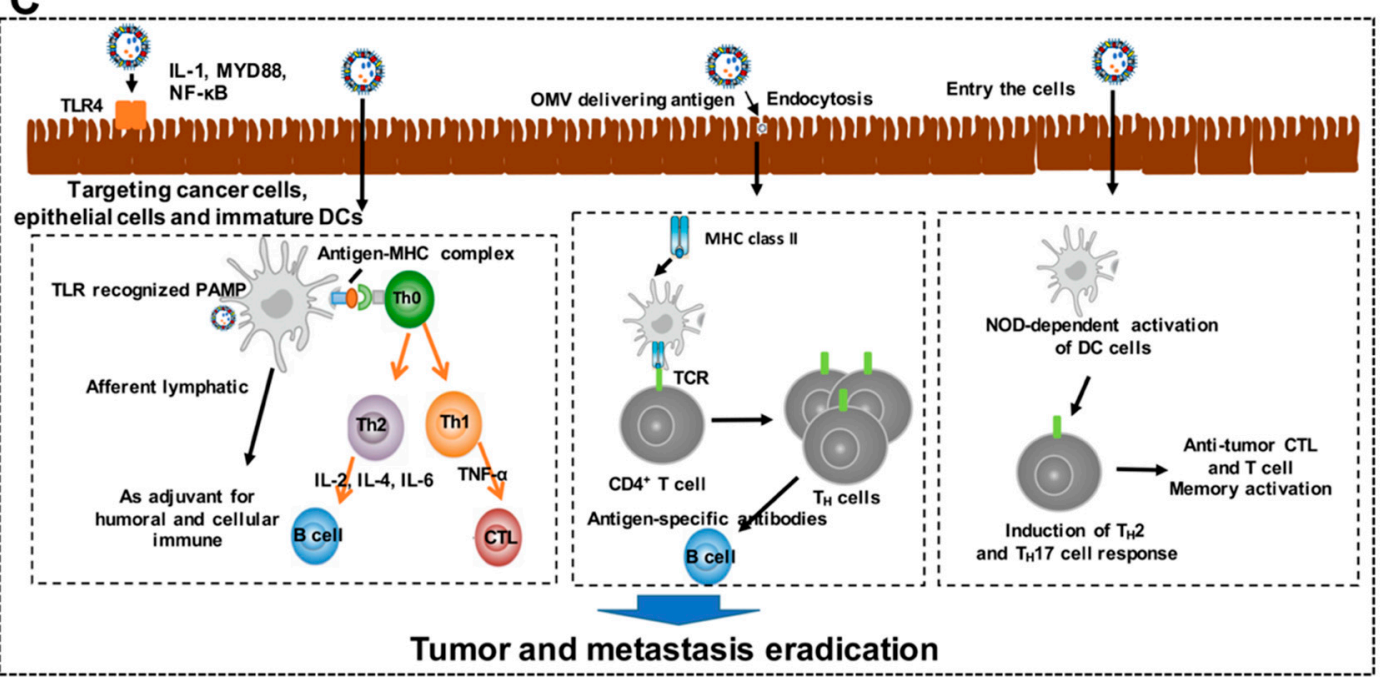

Figure 1. Design of mechanisms underlying the functions and immune modulation of outer membrane vesicles (OMVs) recombinant with heterologous antigens and the pathways through which they gain entry into host cells. (A) OMVs can also cross the mucus barrier in the gut and reach the intestinal epithelium, delivering bacterial antigens to the underlying macrophages, triggering intestinal inflammation. (B) Mechanisms of OMV entry. Pathogenic Gram-negative bacteria are thought to utilize OMVs to interact with host cells during infection. For example, bacteria can use OMVs to mediate the delivery of virulence factors, such as toxins, into host cells, including immune cells, and OMVs may enter host cells through various endocytic routes including clathrin-dependent, caveolin-mediated, lipid raft, and membrane fusion pathways. The most frequently reported mode of OMV entry into host cells involves lipid rafts as OMVs could fuse with lipid rafts to facilitate their entry into host cells. The pathways of cholesterol-independent and clathrin-mediated endocytosis are independent of lipid rafts. 
Moreover, OMVs can enter host cells via the mechanism of membrane fusion in a size-dependent manner. (C) A model for OMVs targeting cancer cells, epithelial cells, and immature dendritic cells (DCs) to mediate immune responses. OMVs can interact directly with epithelial cells and immune cells or they may interact with pattern recognition receptors, such as Toll-like receptor 4 (TLR4), to induce the production of cytokines and chemokines. OMV adjuvant delivered antigen could be recognized by DCs that led to the recruitment of immune cells and stimulated antigen-presenting cells (APC) through toll like receptor (TLR) recognized pathogen-associated molecular patterns (PAMPs). These process enhanced T helper cells production (including Th1 and Th2), and fully amplified cellular and humoral immunity. Furthermore, OMVs delivering antigens can also traffic into non-immune cells and load onto MHC class II molecules. Activated antigen-presenting cells express MHC class II molecules that interact with the $\mathrm{T}$ cell receptor (TCR) on CD4+ T cells to drive antigen-specific $\mathrm{T}$ cell responses, resulting in $\mathrm{T}$ helper cell proliferation, thereby generating antigen-specific antibodies in various tissues. Following entry into host cells, OMVs are also detected by nucleotide-binding oligomerization domain-containing protein 1 (NOD1). Detection and degradation of intracellular OMVs results in the recruitment and activation of DCs to facilitate the development of T cell immunity (Th2 and Th17).

Through the various mechanisms of entry into host cells described above, OMVs not only interact with mucosal epithelial cells, resulting in the production of cytokines and chemokines and the generation of a pro-inflammatory response, but also gain access to the submucosa beyond the host's epithelial cell barrier, and directly interact with various immune cell populations, including neutrophils, macrophages, and DCs. The detailed mechanisms through which OMVs induce inflammation and modulate the host immune system have been reviewed [17]. We restrict our discussion to which OMVs modulate presentation of heterologous antigens targeting cancer cells or other immune cells to facilitate the induction of innate and adaptive immunity and thus to achieve the goal of eradicating tumor cells. Although there are relatively few studies directly investigating the anti-tumor immune response induced by OMVs delivering immunogenic antigens at present, we can reveal the mechanisms of OMV-dependent antitumor immune responses by referring to the interaction between OMVs and the host immune system (Figure 1C). OMVs contain numerous PAMPs, including DNA, RNA, lipoproteins, LPS, and peptidoglycan [49]. These PAMPs of OMVs enable them to engage with host pattern recognition receptors (PRRs) such as Toll-like receptor 4 (TLR4) to initiate pro-inflammatory signaling cascades that lead to the production of cytokines and chemokines [82]. Therefore, OMV-delivered antigens as adjuvants could stimulate APCs through the up-regulated expression of receptors and co-stimulatory molecules, and thus, enhanced Thelper cells production and fully amplified cellular and humoral immune responses [83,84]. Moreover, OMVs that have entered host cells are detected by intracellular host pattern recognition receptors, like nucleotide-binding oligomerization domain-containing protein 1 (NOD1), which seems to be the key intracellular host pattern recognition receptor that is responsible for the establishment of OMV-dependent immune responses. OMVs can mediate inflammatory signaling via the NOD1 receptor, ultimately resulting in the recruitment and activation of DCs to facilitate the development of $\mathrm{T}$ cell immunity $[85,86]$. Furthermore, OMV delivered antigens are presented by APCs to CD4+ T cells, which leads to the generation of antigen-specific B cell responses $[66,87]$. Taken together, OMVs as the adjuvant or delivery vector can be easily phagocytized and processed by APCs, thereby promoting adaptive immune responses including cytotoxic T-cell lymphocyte responses that are crucial for tumor and metastasis eradication.

\subsection{Advantages of $O M V$ s as Cancer Vaccines}

Cancer vaccines commonly include three essential components: tumor special antigen or tumor associated antigen, potent adjuvants, and a delivery system. Loss of any of these components can lead to an ineffective immune response or even drive antigen loss and immune evasion [88]. The appropriate selection of tumor antigens has been reviewed [29]. Here, we restrict our discussion to OMVs as the suitable adjuvants and efficient delivery vectors of tumor antigens. Through the 
suitable design of an OMV, it can be more efficient in delivering tumor antigens or molecule drugs to fulfill antitumor treatment. OMVs can easily be decorated with foreign antigens or epitopes via different synthetic biology approaches, especially by utilizing protein antigen-coding RNA and siRNA interfering gene expression. Furthermore, OMVs are capable of carrying more than one cancer-specific epitope, corresponding to the diversity of tumor antigens (Figure 2). The formation of OMVs involves a sorting mechanism, where proteins are screened and selectively localized to the periplasm or outer membrane. Utilizing this mechanism, different tumor antigens can be delivered to the lumen or surface of vesicles by fusing their coding sequences to those proteins which act as leader peptides for delivery. Some tumor antigens can be located on the surface of OMVs to be better recognized by APCs and thus, induce immune response to kill tumor cells. However, in order to reach deeper tumor tissues to fulfill function, other tumor antigens and small molecule drugs need to be expressed inside the OMVs, which can be hydrophobically encapsulated by lipid bilayers to protect the targeted antigens from degradation of exogenous proteases and early recognition of the immune system [89,90]. Nevertheless, several studies have demonstrated that various antigens delivered to the lumen of OMVs can elicit an effective antibody response and significant protection [19,71].

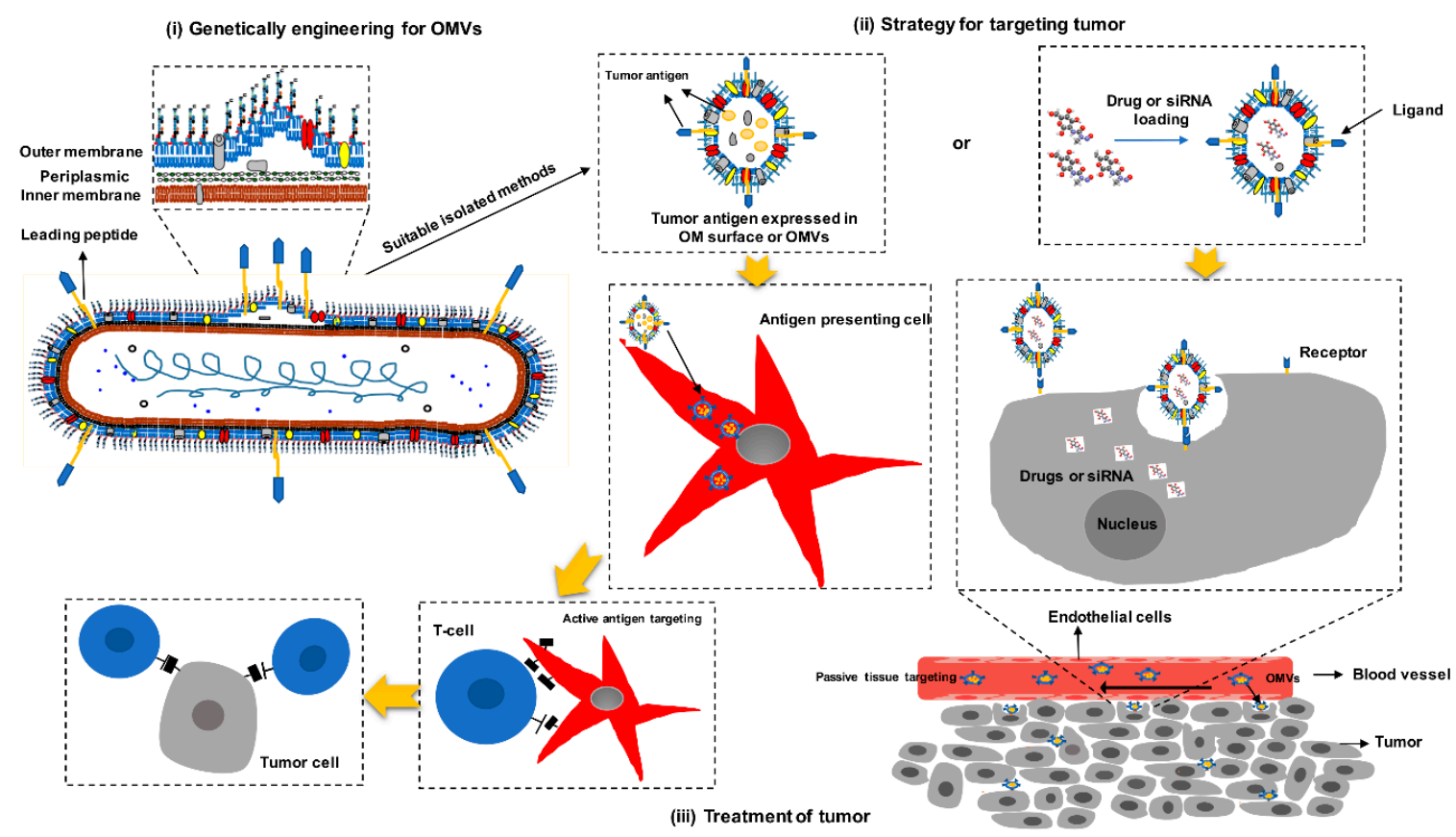

Figure 2. Schematic representation of mechanisms by which OMVs act as carriers to deliver tumor antigens in cancer therapy. Tumor antigens are targeted to the membrane by the leading peptide. OMVs are released from mutant bacterial cells and carry tumor antigens. OMVs travel via blood vessels to arrive at the target tissue. Cells mainly recognize OMVs by ligand-receptor interaction and internalize OMVs by membrane invagination or membrane fusion.

Initially, the strategy of displaying heterologous antigens into OMVs was to transport the target antigens to the periplasm space by fusing to the $\mathrm{N}$-terminal $\beta$-lactamase signal sequence, which was then encapsulated in lumen during the formation of OMVs [71]. Furthermore, Qi Chen et al., tested SlyB as a carrier to direct proteins to the interior of OMVs; cohesin domains were inserted between the Z-domain and INP and functionalized with a dockerin-tagged GFP for cancer cell imaging, indicating the potential role for SlyB and INP as leader peptides to carry antigens [91]. Another delivery system involves fusing antigens with specific proteins such as ClyA, AIDA-I, and OspA which act as leader sequences for antigen delivery [92-94]. Currently the most studied leader peptide directing heterologous antigens to the surface of OMVs is ClyA [95-97]; genetic fusion between recombinant polypeptides and the $\mathrm{C}$-terminus of ClyA results in a functional display of recombinant protein on 
the surface of E. coli and their derived OMVs [96]. Moreover, several heterologous antigens have also been successfully exported to the surface of OMVs when fused to the $\beta$-barrel forming auto transporter AIDA or borrelial lipoprotein OspA [19,94]. In addition to using protein fusion to display antigens, many studies demonstrated that a hemoglobin protease $(\mathrm{Hbp})$ autotransporter platform, originally developed by Jong et al., could also be used to display heterologous antigens on the surface of OMVs [98-100]. Taken together, the design of the location of tumor antigen is a complex process, which needs more research to elucidate and verify; especially, various antigen delivery strategies should pave the way for the genetic design of OMVs as cancer vaccines.

A second factor contributing to OMV potency is their inherent adjuvant properties. Owing to the presence of PAMPs in OMVs, TLR-mediated recognition can occur, thereby driving the inflammatory response in conjunction with complement system activation [101]. PAMPs can also elicit potent Th1-skewed immune responses without the need to add additional adjuvants or delivery systems [83,84].

A third aspect is the integrated delivery system. It is well known that tumor cells are ubiquitous, making the drug diffusion process difficult to control, which may lead to multiple-drug resistance [102]. However, two characteristics of OMVs can solve this problem. OMV size is on a nanometer scale $(<200 \mathrm{~nm})$, which means that they can extravasate into the tumor tissues via the leaky vessels using the enhanced permeability and retention effect; drugs can then be released into the vicinity of the tumor cells $[103,104]$. OMVs are stable and rigid and are therefore not susceptible to drug leakage or degradation in the circulation that occurs commonly with polymeric or liposome-based carriers. OMVs also accumulate selectively in tumor tissue when administered systemically. After arriving at the destination, OMVs can kill tumor cells through direct and indirect effects. To deliver siRNA and other proteins or peptides that are toxic to tumor cells, OMVs can recognize and bind to target cells through ligand-receptor interactions. This occurs via components uniquely expressed on the cell surface [102], such as anti-HER 2 affibody and $\mathrm{HER}_{2}$ (overexpressed in the tumor cells) [105]. In this context, bound carriers are internalized before the drug is released inside the cell. While OMVs can enter APCs via receptor-mediated entrance, transport of materials into cells through membrane fusion has also been reported [101]. More importantly, antigen and immune stimulators that enhance the intensity of immune responses and modulate the direction of the response could be delivered to the same APCs simultaneously, facilitating the production of a robust and effective antigen-specific immune response [101].

In conclusion, OMVs have their distinct immunological and structural features, including their nanometer-scale vesicle structure, self-adjuvant properties, ability to be genetically modified, capacity to present large exogenous proteins, and ability to carry immune stimulators. All these features make the OMV an ideal antigen carrier. Currently, many studies are underway to test the applicability of OMVs as vectors in cancer vaccines.

\subsection{Bacterial OMVs as Cancer Vaccines}

Over a century ago, William Coley developed the first bacteria-based cancer treatment by injecting killed bacteria directly into a tumor after having observed regression of the tumor subsequent to bacterial injection. This suggests that live-attenuated bacteria can potentially function as cancer antigen carriers through genetic modification [106]. In addition, the concept of exploiting bacteria as biological tumor vaccine vectors has existed for some time, and the emergence of the anti-tumor strategy of using live bacteria provided the theoretical basis for the development of OMV as a cancer vaccine by shedding from the bacterial outer membrane. Here, we summarize multiple live bacterial vectors used in preclinical research and clinical trials for anti-cancer therapy to better use these live bacterial vectors for the development of OMV-based cancer vaccines (Table 2). Use of bacteria as vectors for cancer vaccines has included intracellular Salmonella, Listeria, Pseudomonas aeruginosa ( $P$. aeruginosa), and E. coli, for which escape from the phagosome requires virulence factors like listeriolysin $\mathrm{O}$ and phospholipase $C$ to degrade the phagosomal membrane and migrate to neighboring cells by a direct cell-to-cell transfer mechanism. In addition, Listeria and Salmonella vectors have been shown to 
activate innate immunity. This occurs through TLR binding, secretion of inflammatory cytokines and chemokines, upregulation of co-stimulatory molecules, stimulation of antigen specific CD4+ and CD8+ T cells, and suppression of regulatory T cells $[107,108]$. Thus, these two attenuated bacteria are commonly used to deliver cancer antigens. Several other Gram-positive bacteria have also been used, including Clostridium and Bifidobacterium, and these organisms can utilize MHC II molecules to deliver antigens [109]. Therefore, these Gram-positive bacteria can also purify their EVs for cancer vaccine development (Table 2) [110,111]. Although many live bacteria have been used as cancer vaccines in preclinical studies, the biggest problem hindering the entry of such vaccines into clinical trials and clinical application is the balance between safety and immunogenicity. Due to its safety and high efficiency, OMVs provide new choices and ideas for the application of these bacterial vectors as cancer therapeutic vaccines.

OMVs stimulate both humoral and cell-mediated immunity in a manner similar to bacteria; however, they are superior to bacteria in their safety profile and ease of production. Moreover, while intracellular bacteria could be used as live delivery vectors, they could also be utilized to purify OMVs genetically engineered for cancer therapy; several researchers have attempted this and achieved

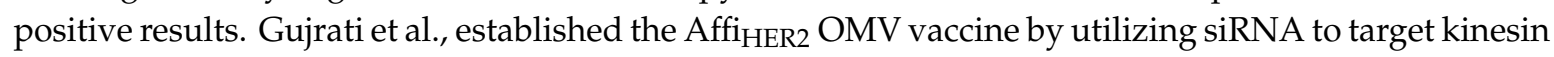
spindle protein and select human epidermal growth factor receptor 2 (HER2) as the receptor in tumor cells [105]. They derived OMVs displaying a HER2-specific affibody from a mutant E. coli strain and injected them into mice. The results indicate that systemic injection of siRNA-packaged OMVs caused targeted gene silencing and induced highly significant tumor growth regression in an animal model. More importantly, the modified OMVs were well tolerated and showed no evidence of nonspecific side effects [105]. Moreover, Wang et al., selected HPV16 E7 protein as a tumor antigen and utilized the Trx protein to present E7 both on the surface and in the lumen of OMVs [101]. In contrast to siRNA recombinant OMVs, these were taken up rapidly by DCs, significantly stimulating the expression of DC maturation markers CD80, CD86, CD83, and CD40. As a result, numbers of interferon-gamma (IFN- $\gamma$ )-expressing splenocytes and IFN- $\gamma$-expressing CD4+ and CD8+ cells increased, and growth of grafted TC-1 tumors in mice was significantly suppressed [101]. Other authors have also investigated recombinant OMVs, for example, EGFRvIII-OMV, which demonstrates the decoration of OMVs with multiple antigens, further corroborating the protective efficacy of the vaccine [88]. Further, given the wide use of OMVs as non-living complex vaccines or delivery vehicles, Oh Youn Kim and colleagues firstly demonstrated the function of OMVs in treating cancer [112]. This showed remarkable capability of E. coli OMVs to effectively induce a long-term antitumor immune response that can fully eradicate the established tumor without notable adverse effects. In particular, this study also showed for the first time that bacterial EVs derived from Gram-positive bacteria Lactobacillus acidophilus and Staphylococcus aureus observed significant antitumor effects, suggesting the potential of using EVs derived from antitumor live Gram-positive bacteria in future clinical applications [112]. Furthermore, these results revealed the potential mechanism of OMV accumulation in tumor tissue and production of IFN- $\gamma$ within the tumor microenvironment to activate antitumor response and expanded the application of OMVs as cancer vaccines not only as delivery platforms but also as antitumor agents. 
Table 2. Major live bacterial vectors used for cancer treatment and showing the potential of OMV- or extracellular vesicle (EV)-based cancer vaccines.

\begin{tabular}{|c|c|c|c|c|c|c|c|c|}
\hline Vaccine Strain & $\begin{array}{l}\text { Gene Mutated } \\
\text { or Modified }\end{array}$ & Descriptions & $\begin{array}{c}\text { Therapeutic Agents } \\
\text { (Tumor Antigen, Immune } \\
\text { molecule, Anti-Tumor Drug) }\end{array}$ & $\begin{array}{l}\text { Prokaryotic/ } \\
\text { Eukaryotic } \\
\text { Expression }\end{array}$ & $\begin{array}{c}\text { Cancer } \\
\text { Indication }\end{array}$ & Clinical Trials & Therapeutic Efficacy\# & References \\
\hline \multicolumn{9}{|c|}{ Salmonella } \\
\hline VNP20009 & $m s b B / P u r$ & $\begin{array}{l}\text { The deletion of } m s b B \text { modifies the lipid-A structure } \\
\text { reducing bacterial ability of TNF- } \alpha \text { induction and } \\
\text { mutation of pur results in bacterial deficiency in } \\
\text { adenine synthesis }\end{array}$ & $\begin{array}{l}\text { Cytokines: IL-18, LIGHT, CCL21; } \\
\text { Cytotoxic agents: TRAL,, FasL; } \\
\text { Regulators: Thrombospondin; } \\
\text { TAA: CEA-scFv, TGF- } \alpha \text {; Prodrug } \\
\text { enzymes: Cytosine deaminase; } \\
\text { si-RNA: sox2-specific, } \\
\text { IDO-specific }\end{array}$ & $\begin{array}{l}\text { Prokaryotic or } \\
\text { eukaryotic } \\
\text { expression }\end{array}$ & $\begin{array}{l}\text { Colon, lung, } \\
\text { breast, cervical } \\
\text { melanoma }\end{array}$ & $\begin{array}{l}\text { Phase I (used for } \\
\text { metastatic } \\
\text { melanoma) }\end{array}$ & $\begin{array}{l}\text { Safety, and targeting to tumor cells, } \\
\text { but no patients experienced } \\
\text { objective tumor regression in } \\
\text { Phase I clinical trial }\end{array}$ & [113-122] \\
\hline $\begin{array}{l}\text { SL3261 } \\
\text { SL7207 et. al. }\end{array}$ & aro- & $\begin{array}{l}\text { The genes aro } A \text { and aroD are responsible for the } \\
\text { biosynthesis of aromatic amino acids }\end{array}$ & $\begin{array}{l}\text { Cytokines: IL-2, IL-12, IL-4, IL-18, } \\
\text { IFN- }- \text {, GM-CSF; Cytotoxic agents: } \\
\text { cytolysin A, Noxa, FlaB, apoptin, } \\
\text { diphtheria toxin; Regulators: } \\
\text { 4-1BBL; TAA: CD20-specific } \\
\text { antibody, HPV16-E7, Survivin, } \\
\text { FLK-1; si-RNA: Bcl-2-specific }\end{array}$ & $\begin{array}{l}\text { Prokaryotic or } \\
\text { eukaryotic } \\
\text { expression }\end{array}$ & $\begin{array}{l}\text { Osteosarcoma, } \\
\text { melanoma, } \\
\text { colon, breast, } \\
\text { cervical, gastric, } \\
\text { neuroblastoma, } \\
\text { lung, prostate }\end{array}$ & None & $\begin{array}{l}\text { Effectively suppressed tumor } \\
\text { growth and metastasis in mouse } \\
\text { model }\end{array}$ & [123-139] \\
\hline SHJ2037 & relA/spoT & $\begin{array}{l}\text { Lacking both RelA and SpoT, cells are unable to } \\
\text { produce ppGpp, a global regulator involving } \\
\text { bacterial adaptation of extreme environment }\end{array}$ & $\begin{array}{l}\text { Regulator: L-asparaginase, TAA: } \\
\text { RGD peptides, TGF- } \alpha\end{array}$ & $\begin{array}{l}\text { Prokaryotic } \\
\text { expression }\end{array}$ & Colon, breast & None & $\begin{array}{l}\text { Effectively suppressed various } \\
\text { solid tumor growth in mouse } \\
\text { model }\end{array}$ & {$[140,141]$} \\
\hline ST8 & asd/gmd & $\begin{array}{l}\text { The gene gmd is in the colanic acid gene cluster and } \\
\text { encodes GDP-mannose 4,6-dehydratase; Salmonella } \\
\text { asd mutants will lyse during growth unless } \\
\text { exogenous DAP is supplied }\end{array}$ & Regulator: Endostatin & $\begin{array}{l}\text { Prokaryotic } \\
\text { expression }\end{array}$ & Colon & None & $\begin{array}{l}\text { Successfully suppressed } \\
\text { angiogenesis and consequently } \\
\text { retards tumor growth }\end{array}$ & [142] \\
\hline LH430 & phoP/phoQ & $\begin{array}{l}\text { The knock-out of } P h o P \text { and } P h o Q \text { that regulate acid } \\
\text { phosphatase synthesis significantly reduces } \\
\text { bacterial survival in macrophages }\end{array}$ & $\begin{array}{l}\text { Regulators: Endostatin; siRNA: } \\
\text { STAT3-specific }\end{array}$ & $\begin{array}{l}\text { Eukaryotic } \\
\text { expression }\end{array}$ & Hepatoma & None & $\begin{array}{l}\text { Stimulated apoptosis and inhibited } \\
\text { angiogenesis in tumors }\end{array}$ & [143] \\
\hline MvP728 & purD/htrA & $\begin{array}{c}\text { The gene purD encodes } 5^{\prime}- \\
\text { phosphoribosylglycinamide synthetase involved in } \\
\text { purine biosynthesis; htrA encodes heat-shock } \\
\text { proteins that are important for virulence of the } \\
\text { bacterium }\end{array}$ & TAA: survivin & $\begin{array}{l}\text { Eukaryotic } \\
\text { expression }\end{array}$ & $\begin{array}{l}\text { Glioblastoma, } \\
\text { colon }\end{array}$ & None & $\begin{array}{l}\text { Enhanced effector-memory CTL } \\
\text { response and inhibited tumor } \\
\text { growth in mouse model }\end{array}$ & [144] \\
\hline$x 4550$ & cya/crp & $\begin{array}{l}\text { The two genes cya and crp encode cAMP (cyclic } \\
\text { adenosine monophosphate) synthetase and cAMP } \\
\text { receptor protein }\end{array}$ & Cytokines: IL-2, TNF- $\alpha$ & $\begin{array}{l}\text { Prokaryotic } \\
\text { expression }\end{array}$ & Melanoma & None & $\begin{array}{l}\text { Inhibited tumor growth as well as } \\
\text { enhanced host survival }\end{array}$ & [145] \\
\hline RE88 & dam & $\begin{array}{l}\text { The gene dam encodes DNA, adenine methylase } \\
\text { sptP is an effector protein of Salmonella }\end{array}$ & TAA: legumain & $\begin{array}{l}\text { Eukaryotic } \\
\text { expression }\end{array}$ & Breast & None & $\begin{array}{l}\text { Effectively suppressed tumor } \\
\text { angiogenesis }\end{array}$ & [146] \\
\hline SB824 & sptP & $\begin{array}{l}\text { SptP is an effector protein of Salmonella } \\
\text { pathogenicity island } 1 \text { (SPI-1), that acts as protein } \\
\text { tyrosine phosphatase/GTPase activating proteins }\end{array}$ & TAA: YopE1-138/p60130-477/M45 & $\begin{array}{l}\text { Prokaryotic } \\
\text { expression }\end{array}$ & Fibrosarcoma & None & $\begin{array}{l}\text { Showed complete tumor } \\
\text { regression }\end{array}$ & [147] \\
\hline
\end{tabular}


Table 2. Cont.

\begin{tabular}{|c|c|c|c|c|c|c|c|c|}
\hline Vaccine Strain & $\begin{array}{l}\text { Gene Mutated } \\
\text { or Modified }\end{array}$ & Descriptions & $\begin{array}{c}\text { Therapeutic Agents } \\
\text { (Tumor Antigen, Immune } \\
\text { molecule, Anti-Tumor Drug) }\end{array}$ & $\begin{array}{l}\text { Prokaryotic/ } \\
\text { Eukaryotic } \\
\text { Expression }\end{array}$ & $\begin{array}{c}\text { Cancer } \\
\text { Indication }\end{array}$ & Clinical Trials & Therapeutic Efficacy\# & References \\
\hline \multicolumn{9}{|c|}{ Listeria $^{*}$} \\
\hline $\begin{array}{l}\text { ADXS11-001 } \\
\text { ADXS31-142 } \\
\text { ADXS31-164 } \\
\text { ADXS-NEO et. } \\
\quad \text { al. }\end{array}$ & $\begin{array}{c}t L L O \\
\text { (Lysteriolysin) }\end{array}$ & $\begin{array}{l}\text { Lm has the ability to replicate in the cytosol of } \\
\text { APCs after escaping from the phagolysosome, } \\
\text { which requires the virulence factor listeriolysin O } \\
\text { (LLO) protein, and targeted antigen fused to a } \\
\text { non-hemolytic LLO }\end{array}$ & $\begin{array}{l}\text { TAA: HPV } 16 \text { E7, PSA, VEGFR2, } \\
\text { HER2, Personal Neo-antigens }\end{array}$ & $\begin{array}{c}\text { Prokaryotic } \\
\text { expression }\end{array}$ & $\begin{array}{l}\text { Cervical, } \\
\text { oropharyngeal, } \\
\text { prostate, colon, } \\
\text { lung, breast, } \\
\text { HER2 } 2^{+} \text {solid } \\
\text { tumors }\end{array}$ & $\begin{array}{l}\text { Phase I (used for } \\
\text { cervical cancer) }\end{array}$ & $\begin{array}{l}36 \% \text { survival for } 12 \text { months and } \\
11 \% \text { response rate were observed } \\
\text { in patients }\end{array}$ & [148-150] \\
\hline $\begin{array}{c}\text { CRS-100 } \\
\text { CRS-207 } \\
\text { ADU-623 } \\
\text { ADU-214 et. al. }\end{array}$ & actA/inlB & $\begin{array}{l}\text { Two virulence genes, } a c t A \text { and internalin B (InlB), } \\
\text { and their combined deletion results in } 1000 \text {-fold } \\
\text { attenuation when compared to wildtype }\end{array}$ & $\begin{array}{l}\text { TAA: Mesothelin, EGFRvIII, } \\
\text { NY-ESO-1, Personal Neo-antigens }\end{array}$ & $\begin{array}{c}\text { Prokaryotic } \\
\text { expression }\end{array}$ & $\begin{array}{l}\text { Pancreatic, lung, } \\
\text { ovarian, } \\
\text { mesothelioma, } \\
\text { prostate }\end{array}$ & $\begin{array}{l}\text { Phase I/II (used } \\
\text { for pancreatic } \\
\text { cancer and } \\
\text { mesothelioma }\end{array}$ & $\begin{array}{l}\text { 37\% of patients survived } 15 \\
\text { months or more, and the } \\
\text { combination with chemotherapy is } \\
\text { more effective }\end{array}$ & {$[151,152]$} \\
\hline $\begin{array}{l}\text { Attenuated } L \text {. } \\
\text { monocytogenes }\end{array}$ & dal/dat & $\begin{array}{l}\text { In the absence of dal and dat expression, replication } \\
\text { of LM can depend only on the availability of } \\
\text { exogenous D-alanine. After introduction of the dal } \\
\text { and dat genes from Bacillus subtilis, the strain was } \\
\text { able to synthesize D-alanine and to replicate to a } \\
\text { limited extent that did not cause severe organ } \\
\text { injuries }\end{array}$ & TAA: $\mathrm{CD} 24$ & $\begin{array}{l}\text { Eukaryotic } \\
\text { expression }\end{array}$ & $\begin{array}{l}\text { Hepatocellular } \\
\text { carcinoma }\end{array}$ & None & $\begin{array}{l}\text { Significantly reduced the tumor } \\
\text { size in mice and increased their } \\
\text { survival from } 0 \% \text { to } 48 \%\end{array}$ & [153] \\
\hline \multicolumn{9}{|c|}{ Clostridium $^{*}$} \\
\hline C. beijerinckii & Non & $\begin{array}{l}\text { E. coli nitroreductase known to activate the nontoxic } \\
\text { prodrug CB } 1954 \text { to a toxic anticancer drug }\end{array}$ & Prodrug enzymes: CB1954 & $\begin{array}{c}\text { Prokaryotic } \\
\text { expression }\end{array}$ & Breast & None & $\begin{array}{l}\text { Lack of toxicity and highly } \\
\text { selective growth in tumors }\end{array}$ & [154] \\
\hline C. acetobutylicum & Non & $\begin{array}{l}\text { C. acetobutylicum was genetically engineered to } \\
\text { express and secrete either mTNF-alpha, IL-2, or the } \\
\text { E. coli cytosine deaminase }\end{array}$ & $\begin{array}{l}\text { Cytokines: TNF- } \alpha, \text { IL-2; Cytotoxic } \\
\text { agents: cytosine deaminase }\end{array}$ & $\begin{array}{c}\text { Prokaryotic } \\
\text { expression }\end{array}$ & Rhabdomyosarcoma & None & $\begin{array}{l}\text { Safety and selective colonization } \\
\text { pattern }\end{array}$ & [155] \\
\hline \multicolumn{9}{|c|}{ Bifidobacterium ${ }^{*}$} \\
\hline B. longum & Non & $\begin{array}{l}\text { Bifidobacterium can selectively germinate and grow } \\
\text { in the hypoxic regions of solid tumors after } \\
\text { intravenous injection }\end{array}$ & $\begin{array}{c}\text { Cytotoxic agents: cytosine } \\
\text { deaminase, TRAIL; Prodrug } \\
\text { enzymes: } 5 \text {-fluorocytosine; TAA: } \\
\text { Wilms' tumor } 1\end{array}$ & $\begin{array}{c}\text { Prokaryotic } \\
\text { expression }\end{array}$ & $\begin{array}{l}\text { Lung, } \\
\text { melanoma; } \\
\text { leukemia }\end{array}$ & None & $\begin{array}{l}\text { Selectively proliferated in tumors } \\
\text { and significantly suppressed } \\
\text { tumor weight and tumor growth }\end{array}$ & [156-159] \\
\hline B. adolescentis & Non & $\begin{array}{l}\text { A shuttle vector, } \mathrm{pBV} 220 \text { was used for expressing } \\
\text { antigens }\end{array}$ & Regulator: Endostatin & $\begin{array}{c}\text { Prokaryotic } \\
\text { expression }\end{array}$ & Liver & None & $\begin{array}{l}\text { Tumor growth in mice was } \\
\text { inhibited by } 23.1 \%\end{array}$ & [160] \\
\hline B. infantis & Non & $\begin{array}{c}\text { B. infantis can selectively localize and proliferate in } \\
\text { the hypoxic environment in several types of solid } \\
\text { tumors }\end{array}$ & TAA: sFlt-1 & $\begin{array}{l}\text { Eukaryotic } \\
\text { expression }\end{array}$ & Lung & None & $\begin{array}{l}\text { Inhibit the tumor growth and } \\
\text { prolong survival time from } 41 \text { days } \\
\text { to } 51 \text { days }\end{array}$ & [161] \\
\hline \multicolumn{9}{|c|}{ Pseudomonas aeruginosa } \\
\hline CHA-OST et. al. & $\begin{array}{l}\text { exoS/exoT/aroA/lasl } \\
\text { fusion with } \\
\text { EXO-S }\end{array}$ & $\begin{array}{l}\text { I, An attenuated live bacterial vector using the type } \\
\text { III secretion system (TTSS) of Pseudomonas } \\
\text { aeruginosa to deliver in vivo tumor antigens }\end{array}$ & TAA: TRP-2, gp100, MUC18 & $\begin{array}{l}\text { Prokaryotic } \\
\text { expression }\end{array}$ & Glioma & None & $\begin{array}{l}100 \% \text { protection in prophylactic } \\
\text { antitumor assay and } 37.5 \% \\
\text { protection in therapeutic antitumor } \\
\text { assay } \\
\end{array}$ & {$[162,163]$} \\
\hline \multicolumn{9}{|c|}{ Escherichia coli } \\
\hline$x 6212$ & $\begin{array}{l}\text { asd, SAH was } \\
\text { cloned into } E \text {. } \\
\text { coli }\end{array}$ & $\begin{array}{l}\text { Staphylococcus aureus } \alpha \text {-hemolysin (SAH) is a } \\
\text { pore-forming protein that is naturally secreted and } \\
\text { kills mammalian cells }\end{array}$ & $\begin{array}{l}\text { Cytotoxic agents:Staphylococcus } \\
\text { aureus } \alpha \text {-hemolysin (SAH) }\end{array}$ & $\begin{array}{c}\text { Prokaryotic } \\
\text { expression }\end{array}$ & Breast & None & $\begin{array}{l}\text { Tumor volume was } 59 \% \text { of } \\
\text { induction compared with control } \\
\text { group }\end{array}$ & {$[164]$} \\
\hline
\end{tabular}




\section{Conclusions and Future Directions}

Currently, OMVs have immense potential to be used as cancer vaccines, but many studies focus only on the insertion of cancer antigens into OMVs and directly use OMVs derived from conventional engineering of E. coli. Genetic engineering of OMVs presents enormous potential to artificially modify different intracellular bacteria such as Salmonella and Listeria to maximize the ability of OMVs to stimulate immune responses, thereby designing an ideal cancer vaccine. In addition, tumor-targeted Gram-positive bacteria such as Clostridium and Bifidobacterium also spontaneously produced EVs through the exfoliation of cell membranes $[110,111]$. Furthermore, bacterial EVs derived from Gram-positive bacteria L. acidophilus and S. aureus showed significant antitumor effects [112]. Thus, Gram-positive bacteria can also be used as targets for the design of vesicle-based cancer vaccines (Table 2).

The challenges that may have to be addressed in OMV cancer vaccine development are as follows: (1) selection of suitable antigens for different types of cancer, (2) enhancing tissue phagocytosis through genetic engineering, and (3) refining the mechanisms of vaccine-induced immune responses and their clinical efficacy [28]. Similarly, the following issues remain to be addressed for OMVs: (1) the high reactogenicity of PAMPs, such as LPS, (2) low expression levels of relevant protective antigens, (3) immuno-dominant antigens that misdirect the immune response, and (4) molecules that are immunosuppressive or otherwise interfering with a protective immune response. Furthermore, among all challenges, immune responses directed to the carrier itself may affect the repeated use of a vaccine based on the same antigen delivery platform. It was reported that pre-existing anti-carrier antibodies may mediate antibody-dependent phagocytosis and promote antigen clearance, thus reducing antigen uptake by APCs and weakening the subsequent immune responses. In addition, undesired responses to OMV components may excessively consume the immune response and thus attenuate specific responses to the target antigen [101]. Therefore, finding a balance between the immune response induced by the OMV itself and the efficiency of antigen delivery is the most important task in designing OMVs as cancer vaccines.

In conclusion, there are still many opportunities and challenges in the development of OMVs, which require more effort and clinical trials. We believe that cancer vaccines based on OMVs can become a safe and effective therapeutic option with prospects for broad application prospects.

Author Contributions: Yingxuan Zhang, Ruizhen Li, and Zheyan Fang wrote the manuscript. Qiong Liu and Xiaotian Huang revised the manuscript for its integrity and accuracy. Qiong Liu approved the final version of this manuscript and takes responsibility for its content.

Funding: This study was supported by the National Natural Science Foundation of China (31760261 and 31660035), the Science and Technology Research project of Jiangxi Provincial Education Department (60224), National Innovation and Entrepreneurship Program for College Students (201910403031), and the Key projects of Jiangxi Natural Science Foundation (20171ACB20003).

Conflicts of Interest: The authors declare no conflict of interest.

\section{References}

1. World Health Organization. The Global Burden of Disease: 2004 Update; World Health Organization: Geneva, Switzerland, 2008.

2. Bray, F. Global cancer statistics. CA Cancer J. Clin. 2018, 8, 394-424. [CrossRef] [PubMed]

3. Berzofsky, J.A.; Terabe, M.; Trepel, J.B.; Pastan, I.; Stroncek, D.F.; Morris, J.C.; Wood, L.V. Cancer vaccine strategies: Translation from mice to human clinical trials. Cancer Immunol. Immunother. 2018, 67, 1863-1869. [CrossRef] [PubMed]

4. Da Silva, J.L.; Dos Santos, A.L.S.; Nunes, N.C.C.; de Moraes Lino da Silva, F.; Ferreira, C.G.M.; de Melo, A.C. Cancer immunotherapy: The art of targeting the tumor immune microenvironment. Cancer Chemother. Pharmacol. 2019. [CrossRef] [PubMed]

5. Nakahara, Y.; Kouro, T.; Igarashi, Y.; Kawahara, M.; Sasada, T. Prospects for a personalized peptide vaccine against lung cancer. Expert Rev. Vaccines 2019, 1-7. [CrossRef] [PubMed] 
6. Osipov, A.; Murphy, A.; Zheng, L. From immune checkpoints to vaccines: The past, present and future of cancer immunotherapy. Adv. Cancer Res. 2019, 143, 63-144. [CrossRef] [PubMed]

7. Basu, A.; Ramamoorthi, G.; Jia, Y.; Faughn, J.; Wiener, D.; Awshah, S.; Kodumudi, K.; Czerniecki, B.J. Immunotherapy in breast cancer: Current status and future directions. Adv. Cancer Res. 2019, 143, 295-349. [CrossRef] [PubMed]

8. Limacher, J.M.; Quoix, E. TG4010: A therapeutic vaccine against MUC1 expressing tumors. Oncoimmunology 2012, 1, 791. [CrossRef] [PubMed]

9. Randeep, S.; Charles, B. L-BLP25: A peptide vaccine strategy in non small cell lung cancer. Clin. Cancer Res. J. Am. Assoc. Cancer Res. 2007, 13, 4652-4654.

10. Rodríguez, P.C.; Rodríguez, G.; González, G.; Lage, A. Clinical development and perspectives of CIMAvax EGF, Cuban vaccine for non-small-cell lung cancer therapy. Med. Rev. 2010, 12, 17-23.

11. Johnson, D.B.; Puzanov, I.; Kelley, M.C. Talimogene laherparepvec (T-VEC) for the treatment of advanced melanoma. Immunotherapy 2015, 7, 611-619. [CrossRef] [PubMed]

12. Knox, K.W.; Vesk, M.; Work, E. Relation between excreted lipopolysaccharide complexes and surface structures of a lysine-limited culture of Escherichia coli. J. Bacteriol. 1966, 92, 1206-1217. [PubMed]

13. Lee, E.Y.; Choi, D.Y.; Kim, D.K.; Kim, J.W.; Park, J.O.; Kim, S.; Kim, S.H.; Desiderio, D.M.; Kim, Y.K.; Kim, K.P.; et al. Gram-positive bacteria produce membrane vesicles: Proteomics-based characterization of Staphylococcus aureus-derived membrane vesicles. Proteomics 2009, 9, 5425-5436. [CrossRef] [PubMed]

14. Shockman, G.D.; Barrett, J.F. Structure, function, and assembly of cell walls of gram-positive bacteria. Annu. Rev. Microbiol. 1983, 37, 501-527. [CrossRef] [PubMed]

15. Brown, L.; Wolf, J.M.; Prados-Rosales, R.; Casadevall, A. Through the wall: Extracellular vesicles in Gram-positive bacteria, mycobacteria and fungi. Nat. Rev. Microbiol. 2015, 13, 620-630. [CrossRef] [PubMed]

16. Schwechheimer, C.; Kuehn, M.J. Outer-membrane vesicles from Gram-negative bacteria: Biogenesis and functions. Nat. Rev. Microbiol. 2015, 13, 605-619. [CrossRef] [PubMed]

17. Kaparakis-Liaskos, M.; Ferrero, R.L. Immune modulation by bacterial outer membrane vesicles. Nat. Rev. Immunol. 2015, 15, 375-387. [CrossRef] [PubMed]

18. Kesty, N.C.; Kuehn, M.J. Incorporation of heterologous outer membrane and periplasmic proteins into Escherichia coli outer membrane vesicles. J. Biol. Chem. 2004, 279, 2069-2076. [CrossRef] [PubMed]

19. Fantappiè, L.; Santis, M.D.; Chiarot, E.; Carboni, F.; Bensi, G.; Jousson, O.; Margarit, I.; Grandi, G. Antibody-mediated immunity induced by engineered Escherichia coli OMVs carrying heterologous antigens in their lumen. J. Extracell. Vesicles 2014, 3, 24015. [CrossRef] [PubMed]

20. Sandro, R.; Leitner, D.R.; Jeremy, I.; Kristina, S.P.; Feldman, M.F.; Georg, K.; Joachim, R.; Stefan, S. Intranasal immunization with nontypeable Haemophilus influenzae outer membrane vesicles induces cross-protective immunity in mice. PLOS ONE 2012, 7, 520-521.

21. Wong, K.K.; Li, W.A.; Mooney, D.J.; Dranoff, G. Advances in Therapeutic Cancer Vaccines. Adv. Immunol. 2016, 130, 191-249. [CrossRef]

22. Gillison, M.L.; Chaturvedi, A.K.; Lowy, D.R. HPV prophylactic vaccines and the potential prevention of noncervical cancers in both men and women. Cancer 2010, 113, 3036-3046. [CrossRef] [PubMed]

23. Sobol, R.E. The rationale for prophylactic cancer vaccines and need for a paradigm shift. Cancer Gene Ther. 2006, 13, 725. [CrossRef] [PubMed]

24. Alex, K.; Hanna, M.G. Overview of the cancer vaccine field: Are we moving forward? Hum. Vaccines 2012, 8, 1135-1140.

25. Zhang, X.; Sharma, P.K.; Peter Goedegebuure, S.; Gillanders, W.E. Personalized cancer vaccines: Targeting the cancer mutanome. Vaccine 2017, 35, 1094-1100. [CrossRef] [PubMed]

26. O’Brien, L.J.; Guillerey, C.; Radford, K.J. Can Dendritic Cell Vaccination Prevent Leukemia Relapse? Cancers 2019, 11. [CrossRef] [PubMed]

27. Badrinath, N.; Yoo, S.Y. Recent Advances in Cancer Stem Cell-Targeted Immunotherapy. Cancers $2019,11$. [CrossRef] [PubMed]

28. Banchereau, J.; Palucka, K. Immunotherapy: Cancer vaccines on the move. Nat. Rev. Clin. Oncol. 2017, 15, 9. [CrossRef]

29. Tran, T.; Blanc, C.; Granier, C.; Saldmann, A.; Tanchot, C.; Tartour, E. Therapeutic cancer vaccine: Building the future from lessons of the past. Semin. Immunopathol. 2019, 41, 69-85. [CrossRef] 
30. Collichio, F.A.; Amatruda, T.; Senzer, N.N.; Chesney, J.; Delman, K.A.; Spitler, L.E.; Puzanov, I.; Doleman, S.; Ye, Y.; Vanderwalde, A.M. OPTiM: A randomized phase III trial of talimogene laherparepvec (T-VEC) versus subcutaneous (SC) granulocyte-macrophage colony-stimulating factor (GM-CSF) for the treatment (tx) of unresected stage IIIB/C and IV melanoma. J. Clin. Oncol. 2014, 9, 74-75.

31. Thara, E.; Dorff, T.B.; Averia-Suboc, M.; Luther, M.; Reed, M.E.; Pinski, J.K.; Quinn, D.I. Immune response to sipuleucel-T in prostate cancer. Cancers 2012, 4, 420-441. [CrossRef]

32. Cecco, S.; Muraro, E.; Giacomin, E.; Martorelli, D.; Lazzarini, R.; Baldo, P.; Dolcetti, R. Cancer vaccines in phase II/III clinical trials: State of the art and future perspectives. Curr. Cancer Drug Targets 2011, 11, 85-102. [CrossRef] [PubMed]

33. Del Vecchio, C.A.; Gordon, L.; Wong, A.J. Targeting EGF receptor variant III: Tumor-specific peptide vaccination for malignant gliomas. Expert Rev. Vaccines 2012, 11, 133-144. [CrossRef] [PubMed]

34. Elsamadicy, A.A.; Chongsathidkiet, P.; Desai, R.; Woroniecka, K.; Farber, S.H.; Fecci, P.E.; Sampson, J.H. Prospect of rindopepimut in the treatment of glioblastoma. Expert Opin. Biol. Ther. 2017, 17, 507. [CrossRef] [PubMed]

35. Mittendorf, E.A.; Clifton, G.T.; Holmes, J.P.; Clive, K.S.; Ritesh, P.; Benavides, L.C.; Gates, J.D.; Sears, A.K.; Alexander, S.; Sathibalan, P. Clinical trial results of the HER-2/neu (E75) vaccine to prevent breast cancer recurrence in high-risk patients: From US Military Cancer Institute Clinical Trials Group Study I-01 and I-02. Cancer 2012, 118, 2594-2602. [CrossRef] [PubMed]

36. Klebanoff, C.A.; Acquavella, N.; Yu, Z.; Restifo, N.P. Therapeutic cancer vaccines: Are we there yet? Immunol. Rev. 2011, 239, 27-44. [CrossRef] [PubMed]

37. Tumeh, P.C.; Harview, C.L.; Yearley, J.H.; I Peter, S.; Taylor, E.J.M.; Lidia, R.; Bartosz, C.; Marko, S.; Gina, H.; Voicu, C. PD-1 blockade induces responses by inhibiting adaptive immune resistance. Nature 2014, 515, 568. [CrossRef] [PubMed]

38. Royal, R.E.; Levy, C.K.; Mathur, A.; Hughes, M.; Kammula, U.S.; Sherry, R.M.; Topalian, S.L.; Yang, J.C.; Lowy, I.; Rosenberg, S.A. Phase 2 trial of single agent Ipilimumab (anti-CTLA-4) for locally advanced or metastatic pancreatic adenocarcinoma. J. Immunother. 2010, 33, 828-833. [CrossRef]

39. Burg, S.H.V.D.; Arens, R.; Ossendorp, F.; Hall, T.V.; Melief, C.J.M. Vaccines for established cancer: Overcoming the challenges posed by immune evasion. Nat. Rev. Cancer 2016, 16, 219. [CrossRef]

40. Van, D.P.L.; Stork, M. Outer membrane vesicles as platform vaccine technology. Biotechnol. J. 2015, 10, 1689-1706.

41. Ellis, T.N.; Kuehn, M.J. Virulence and immunomodulatory roles of bacterial outer membrane vesicles. Microbiol. Mol. Biol. Rev. 2010, 74, 81-94. [CrossRef]

42. Bachmann, M.F.; Jennings, G.T. Vaccine delivery: A matter of size, geometry, kinetics and molecular patterns. Nat. Rev. Immunol. 2010, 10, 787-796. [CrossRef] [PubMed]

43. Perrett, K.P.; McVernon, J.; Richmond, P.C.; Marshall, H.; Nissen, M.; August, A.; Percell, S.; Toneatto, D.; Nolan, T. Immune responses to a recombinant, four-component, meningococcal serogroup B vaccine (4CMenB) in adolescents: A phase III, randomized, multicentre, lot-to-lot consistency study. Vaccine 2015, 33, 5217-5224. [CrossRef] [PubMed]

44. Acevedo, R.; Fernández, S.; Zayas, C.; Acosta, A.; Sarmiento, M.E.; Ferro, V.A.; Rosenqvist, E.; Campa, C.; Cardoso, D.; Garcia, L. Bacterial Outer Membrane Vesicles and Vaccine Applications. Front. Immunol. 2014, 5, 121. [CrossRef] [PubMed]

45. Reyes, F.; Tirado, Y.; Puig, A.; Borrero, R.; Reyes, G. Immunogenicity and cross-reactivity against Mycobacterium tuberculosis; of proteoliposomes derived from Mycobacterium bovis BCG. BMC Immunol. 2013, 14, S7. [PubMed]

46. Rodriguez, L.; Tirado, Y.; Reyes, F.; Puig, A.; Kadir, R.; Borrero, R.; Fernandez, S.; Reyes, G.; Alvarez, N.; Garcia, M.A. Proteoliposomes from Mycobacterium smegmatis induce immune cross-reactivity against Mycobacterium tuberculosis antigens in mice. Vaccine 2011, 29, 6236-6241. [CrossRef] [PubMed]

47. Johan, H.; Philipp, O.; Richard, A.; Tatley, M.V.; Naess, L.; Aaberge, I.S.; Yvonne, G.; Anne, M.N.; Jane, O.H.; Einar, R. Vaccines against meningococcal serogroup B disease containing outer membrane vesicles (OMV): Lessons from past programs and implications for the future. Hum. Vaccines Immunother. 2013, 9, 1241-1253.

48. Fernandez, S.; Fajardo, E.M.; Mandiarote, A.; Padron, M.A. A proteoliposome formulation derived from Bordetella pertussis induces;protection in two murine challenge models. BMC Immunol. 2013, 14, 1-4. [CrossRef] 
49. O'Donoghue, E.J.; Krachler, A.M. Mechanisms of outer membrane vesicle entry into host cells. Cell. Microbiol. 2016, 18, 1508-1517. [CrossRef]

50. Carvalho, A.L.; Fonseca, S.; Miquel-Clopes, A.; Cross, K.; Kok, K.S.; Wegmann, U.; Gil-Cordoso, K.; Bentley, E.G.; Al Katy, S.H.M.; Coombes, J.L.; et al. Bioengineering commensal bacteria-derived outer membrane vesicles for delivery of biologics to the gastrointestinal and respiratory tract. J. Extracell. Vesicles 2019, 8, 1632100. [CrossRef]

51. Liu, Q.; Liu, Q.; Yi, J.; Liang, K.; Hu, B.; Zhang, X.; Curtiss, R., 3rd; Kong, Q. Outer membrane vesicles from flagellin-deficient Salmonella enterica serovar Typhimurium induce cross-reactive immunity and provide cross-protection against heterologous Salmonella challenge. Sci. Rep. 2016, 6, 34776. [CrossRef]

52. Hays, M.P.; Houben, D.; Yang, Y.; Luirink, J.; Hardwidge, P.R. Immunization with Skp Delivered on Outer Membrane Vesicles Protects Mice Against Enterotoxigenic Escherichia coli Challenge. Front. Cell. Infect. Microbiol. 2018, 8, 132. [CrossRef] [PubMed]

53. Marion, C.R.; Lee, J.; Sharma, L.; Park, K.S.; Lee, C.; Liu, W.; Liu, P.; Feng, J.; Gho, Y.S.; Dela Cruz, C.S. Toll-like Receptors 2 and 4 Modulate Pulmonary Inflammation and Host Factors Mediated by Outer Membrane Vesicles derived from Acinetobacter baumannii. Infect. Immun. 2019. [CrossRef] [PubMed]

54. Huang, W.; Yao, Y.; Long, Q.; Yang, X.; Sun, W.; Liu, C.; Jin, X.; Li, Y.; Chu, X.; Chen, B.; et al. Immunization against multidrug-resistant Acinetobacter baumannii effectively protects mice in both pneumonia and sepsis models. PLoS ONE 2014, 9, e100727. [CrossRef] [PubMed]

55. Shang, E.S.; Champion, C.I.; Wu, X.Y.; Skare, J.T.; Blanco, D.R.; Miller, J.N.; Lovett, M.A. Comparison of protection in rabbits against host-adapted and cultivated Borrelia burgdorferi following infection-derived immunity or immunization with outer membrane vesicles or outer surface protein A. Infect. Immun. 2000, 68, 4189-4199. [CrossRef]

56. Nieves, W.; Asakrah, S.; Qazi, O.; Brown, K.A.; Kurtz, J.; Aucoin, D.P.; McLachlan, J.B.; Roy, C.J.; Morici, L.A. A naturally derived outer-membrane vesicle vaccine protects against lethal pulmonary Burkholderia pseudomallei infection. Vaccine 2011, 29, 8381-8389. [CrossRef]

57. Zurita, M.E.; Wilk, M.M.; Carriquiriborde, F.; Bartel, E.; Moreno, G.; Misiak, A.; Mills, K.H.G.; Hozbor, D. A Pertussis Outer Membrane Vesicle-Based Vaccine Induces Lung-Resident Memory CD4 T Cells and Protection Against Bordetella pertussis, Including Pertactin Deficient Strains. Front. Cell. Infect. Microbiol. 2019, 9, 125. [CrossRef] [PubMed]

58. Kim, O.Y.; Hong, B.S.; Park, K.S.; Yoon, Y.J.; Choi, S.J.; Lee, W.H.; Roh, T.Y.; Lotvall, J.; Kim, Y.K.; Gho, Y.S. Immunization with Escherichia coli outer membrane vesicles protects bacteria-induced lethality via Th1 and Th17 cell responses. J. Immunol. 2013, 190, 4092-4102. [CrossRef] [PubMed]

59. Xu, K.; Zhao, Q.; Wen, X.; Wu, R.; Wen, Y.; Huang, X.; Huang, Y.; Yan, Q.; Han, X.; Ma, X.; et al. A trivalent Apx-fusion protein delivered by $E$. coli outer membrane vesicles induce protection against Actinobacillus pleuropneumoniae of serotype 1 and 7 challenge in a murine model. PLOS ONE 2018, 13, e0191286. [CrossRef] [PubMed]

60. Keenan, J.; Oliaro, J.; Domigan, N.; Potter, H.; Aitken, G.; Allardyce, R.; Roake, J. Immune response to an 18-kilodalton outer membrane antigen identifies lipoprotein 20 as a Helicobacter pylori vaccine candidate. Infect. Immunol. 2000, 68, 3337-3343. [CrossRef]

61. Lee, W.H.; Choi, H.I.; Hong, S.W.; Kim, K.S.; Gho, Y.S.; Jeon, S.G. Vaccination with Klebsiella pneumoniae-derived extracellular vesicles protects against bacteria-induced lethality via both humoral and cellular immunity. Exp. Mol. Med. 2015, 47, e183. [CrossRef]

62. Bai, X.; Findlow, J.; Borrow, R. Recombinant protein meningococcal serogroup B vaccine combined with outer membrane vesicles. Expert Opin. Biol. Ther. 2011, 11, 969-985. [CrossRef] [PubMed]

63. Etchart, N.; Baaten, B.; Andersen, S.R.; Hyland, L.; Wong, S.Y.; Hou, S. Intranasal immunisation with inactivated RSV and bacterial adjuvants induces mucosal protection and abrogates eosinophilia upon challenge. Eur. J. Immunol. 2006, 36, 1136-1144. [CrossRef] [PubMed]

64. Nakao, R.; Hasegawa, H.; Ochiai, K.; Takashiba, S.; Ainai, A.; Ohnishi, M.; Watanabe, H.; Senpuku, H. Outer membrane vesicles of Porphyromonas gingivalis elicit a mucosal immune response. PLoS ONE 2011, 6, e26163. [CrossRef]

65. Liu, Q.; Yi, J.; Liang, K.; Zhang, X.; Liu, Q. Outer Membrane Vesicles Derived from Salmonella Enteritidis Protect against the Virulent Wild-Type Strain Infection in a Mouse Model. J. Microbiol. Biotechnol. 2017, 27, 1519-1528. [CrossRef] [PubMed] 
66. Alaniz, R.C.; Deatherage, B.L.; Lara, J.C.; Cookson, B.T. Membrane vesicles are immunogenic facsimiles of Salmonella typhimurium that potently activate dendritic cells, prime B and T cell responses, and stimulate protective immunity in vivo. J. Immunol. 2007, 179, 7692-7701. [CrossRef] [PubMed]

67. Camacho, A.I.; Irache, J.M.; de Souza, J.; Sanchez-Gomez, S.; Gamazo, C. Nanoparticle-based vaccine for mucosal protection against Shigella flexneri in mice. Vaccine 2013, 31, 3288-3294. [CrossRef] [PubMed]

68. Mitra, S.; Sinha, R.; Mitobe, J.; Koley, H. Development of a cost-effective vaccine candidate with outer membrane vesicles of a tolA-disrupted Shigella boydii strain. Vaccine 2016, 34, 1839-1846. [CrossRef]

69. Bishop, A.L.; Tarique, A.A.; Patimalla, B.; Calderwood, S.B.; Qadri, F.; Camilli, A. Immunization of mice with vibrio cholerae outer-membrane vesicles protects against hyperinfectious challenge and blocks transmission. J. Infect. Dis. 2012, 205, 412-421. [CrossRef]

70. Bartolini, E.; Ianni, E.; Frigimelica, E.; Petracca, R.; Galli, G.; Scorza, F.B.; Norais, N.; Laera, D.; Giusti, F.; Pierleoni, A. Recombinant outer membrane vesicles carrying Chlamydia muridarum HtrA induce antibodies that neutralize chlamydial infection in vitro. J. Extracell. Vesicles 2013, 2, 20181. [CrossRef]

71. Muralinath, M.; Kuehn, M.J.; Roland, K.L.; Curtiss, R., 3rd. Immunization with Salmonella enterica serovar Typhimurium-derived outer membrane vesicles delivering the pneumococcal protein PspA confers protection against challenge with Streptococcus pneumoniae. Infect. Immun. 2011, 79, 887-894. [CrossRef]

72. Hickey, C.A.; Kuhn, K.A.; Donermeyer, D.L.; Porter, N.T.; Jin, C.; Cameron, E.A.; Jung, H.; Kaiko, G.E.; Wegorzewska, M.; Malvin, N.P. Colitogenic Bacteroides thetaiotaomicron Antigens Access Host Immune Cells in a Sulfatase-Dependent Manner via Outer Membrane Vesicles. Cell Host Microbe 2015, 17, 672-680. [CrossRef] [PubMed]

73. Ritter, T.E.; Fajardo, O.; Matsue, H.; Anderson, R.G.; Lacey, S.W. Folate receptors targeted to clathrin-coated pits cannot regulate vitamin uptake. Proc. Natl. Acad. Sci. USA 1995, 92, 3824-3828. [CrossRef] [PubMed]

74. Dries, V.; Vandenbroucke, R.E.; Jones, A.T.; Joanna, R.; Joseph, D.; De Smedt, S.C.; Sanders, N.N.; Kevin, B. The use of inhibitors to study endocytic pathways of gene carriers: Optimization and pitfalls. Mol. Ther. J. Am. Soc. Gene Ther. 2010, 18, 561.

75. Rewatkar, P.V.; Parton, R.G.; Parekh, H.S.; Parat, M.O. Are caveolae a cellular entry route for non-viral therapeutic delivery systems? Adv. Drug. Deliv. Rev. 2015, 91, 92-108. [CrossRef] [PubMed]

76. Parker, H.; Chitcholtan, K.; Hampton, M.B.; Keenan, J.I. Uptake of Helicobacter pylori outer membrane vesicles by gastric epithelial cells. Infect. Immun. 2010, 78, 5054-5061. [CrossRef] [PubMed]

77. Mulcahy, L.A.; Pink, R.C.; Carter, D.R.F. Routes and mechanisms of extracellular vesicle uptake. J. Extracell. Vesicles 2014, 3, 24641. [CrossRef] [PubMed]

78. Sharpe, S.W.; Kuehn, M.J.; Mason, K.M. Elicitation of epithelial cell-derived immune effectors by outer membrane vesicles of nontypeable Haemophilus influenzae. Infect. Immun. 2011, 79, 4361-4369. [CrossRef] [PubMed]

79. Jan, A.T. Outer Membrane Vesicles (OMVs) of Gram-negative Bacteria: A Perspective Update. Front. Microbiol. 2017, 8, 1053. [CrossRef]

80. Weiner, A.; Mellouk, N.; Lopez-Montero, N.; Chang, Y.Y.; Souque, C.; Schmitt, C.; Enninga, J. Macropinosomes are Key Players in Early Shigella Invasion and Vacuolar Escape in Epithelial Cells. PLoS Pathog. 2016, 12, e1005602. [CrossRef]

81. Jet Phey, L.; Gleeson, P.A. Macropinocytosis: An endocytic pathway for internalising large gulps. Immunol. Cell Biol. 2011, 89, 836.

82. Soderblom, T.; Oxhamre, C.; Wai, S.N.; Uhlen, P.; Aperia, A.; Uhlin, B.E.; Richter-Dahlfors, A. Effects of the Escherichia coli toxin cytolysin A on mucosal immunostimulation via epithelial Ca2+ signalling and Toll-like receptor 4. Cell. Microbiol. 2005, 7, 779-788. [CrossRef] [PubMed]

83. Liu, Q.; Tan, K.; Yuan, J.; Song, K.; Li, R.; Huang, X.; Liu, Q. Flagellin-deficient outer membrane vesicles as adjuvant induce cross-protection of Salmonella Typhimurium outer membrane proteins against infection by heterologous Salmonella serotypes. Int. J. Med Microbiol. 2018, 308, 796-802. [CrossRef] [PubMed]

84. Tan, K.; Li, R.; Huang, X.; Liu, Q. Outer Membrane Vesicles: Current Status and Future Direction of These Novel Vaccine Adjuvants. Front. Microbiol. 2018, 9, 783. [CrossRef] [PubMed]

85. Kaparakis, M.; Turnbull, L.; Carneiro, L.; Firth, S.; Coleman, H.A.; Parkington, H.C.; Le Bourhis, L.; Karrar, A.; Viala, J.; Mak, J.; et al. Bacterial membrane vesicles deliver peptidoglycan to NOD1 in epithelial cells. Cell. Microbiol. 2010, 12, 372-385. [CrossRef] [PubMed] 
86. Chatterjee, D.; Chaudhuri, K. Vibrio cholerae O395 outer membrane vesicles modulate intestinal epithelial cells in a NOD1 protein-dependent manner and induce dendritic cell-mediated Th2/Th17 cell responses. J. Biol. Chem. 2013, 288, 4299-4309. [CrossRef] [PubMed]

87. Aghasadeghi, M.R.; Salmani, A.S.; Sadat, S.M.; Javadi, F.; Memarnejadian, A.; Vahabpour, R.; Zabihollahi, R.; Moshiri, A.; Siadat, S.D. Application of outer membrane vesicle of Neisseria meningitidis serogroup B as a new adjuvant to induce strongly Th1-oriented responses against HIV-1. Curr. HIV Res. 2011, 9, 630-635. [CrossRef]

88. Grandi, A.; Tomasi, M.; Zanella, I.; Ganfini, L.; Caproni, E.; Fantappiè, L.; Irene, C.; Frattini, L.; Isaac, S.J.; König, E. Synergistic Protective Activity of Tumor-Specific Epitopes Engineered in Bacterial Outer Membrane Vesicles. Front. Oncol. 2017, 7, 253. [CrossRef]

89. Bonnington, K.E.; Kuehn, M.J. Protein selection and export via outer membrane vesicles. Biochim. Et Biophys. Acta 2014, 1843, 1612-1619. [CrossRef]

90. Kolling, G.L.; Matthews, K.R. Export of virulence genes and Shiga toxin by membrane vesicles of Escherichia coli O157:H7. Appl. Environ.Microbiol. 1999, 65, 1843-1848.

91. Chen, Q.; Rozovsky, S.; Chen, W. Engineering multi-functional bacterial outer membrane vesicles as modular nanodevices for biosensing and bioimaging. Chem. Commun. 2017, 53, 7569-7572. [CrossRef]

92. Berthiaume, F.; Leblond, M.F.; Harel, J.; Mourez, M. Growth-phase-dependent expression of the operon coding for the glycosylated autotransporter adhesin AIDA-I of pathogenic Escherichia coli. FEMS Microbiol. Lett. 2010, 311, 176-184. [CrossRef]

93. Kim, S.H.; Kim, K.S.; Lee, S.R.; Kim, E.; Kim, M.S.; Lee, E.Y.; Gho, Y.S.; Kim, J.W.; Bishop, R.E.; Chang, K.T. Structural modifications of outer membrane vesicles to refine them as vaccine delivery vehicles. Biochim. Et Biophys. Acta 2009, 1788, 2150-2159. [CrossRef] [PubMed]

94. Salverda, M.L.; Meinderts, S.M.; Hamstra, H.J.; Wagemakers, A.; Hovius, J.W.; van der Ark, A.; Stork, M.; van der Ley, P. Surface display of a borrelial lipoprotein on meningococcal outer membrane vesicles. Vaccine 2016, 34, 1025-1033. [CrossRef] [PubMed]

95. Sun, N.W.; Lindmark, B.; Söderblom, T.; Takade, A.; Westermark, M.; Oscarsson, J.; Jass, J.; Richter-Dahlfors, A.; Mizunoe, Y.; Uhlin, B.E. Vesicle-Mediated Export and Assembly of Pore-Forming Oligomers of the Enterobacterial ClyA Cytotoxin. Cell 2003, 115, 25-35.

96. Kim, J.Y.; Doody, A.M.; Chen, D.J.; Cremona, G.H.; Shuler, M.L.; Putnam, D.; Delisa, M.P. Engineered Bacterial Outer Membrane Vesicles with Enhanced Functionality. J. Mol. Biol. 2008, 380, 51-66. [CrossRef]

97. Chen, D.J.; Nikolaus, O.; Metzger, S.M.; Elizabeth, B.; Doody, A.M.; Delisa, M.P.; David, P. Delivery of foreign antigens by engineered outer membrane vesicle vaccines. Proc. Natl. Acad. Sci. USA 2010, 107, 3099-3104. [CrossRef] [PubMed]

98. Kuipers, K.; Daleke-Schermerhorn, M.H.; Jong, W.S.; ten Hagen-Jongman, C.M.; van Opzeeland, F.; Simonetti, E.; Luirink, J.; de Jonge, M.I. Salmonella outer membrane vesicles displaying high densities of pneumococcal antigen at the surface offer protection against colonization. Vaccine 2015, 33, 2022-2029. [CrossRef]

99. Daleke-Schermerhorn, M.H.; Felix, T.; Soprova, Z.; Ten Hagen-Jongman, C.M.; Vikstrom, D.; Majlessi, L.; Beskers, J.; Follmann, F.; de Punder, K.; van der Wel, N.N.; et al. Decoration of outer membrane vesicles with multiple antigens by using an autotransporter approach. Appl. Environ. Microbiol. 2014, 80, 5854-5865. [CrossRef] [PubMed]

100. Jong, W.S.; Daleke-Schermerhorn, M.H.; Vikstrom, D.; Ten Hagen-Jongman, C.M.; de Punder, K.; van der Wel, N.N.; van de Sandt, C.E.; Rimmelzwaan, G.F.; Follmann, F.; Agger, E.M.; et al. An autotransporter display platform for the development of multivalent recombinant bacterial vector vaccines. Microb. Cell Factories 2014, 13, 162. [CrossRef]

101. Wang, S.; Huang, W.; Li, K.; Yao, Y.; Yang, X.; Bai, H.; Sun, W.; Liu, C.; Ma, Y. Engineered outer membrane vesicle is potent to elicit HPV16E7-specific cellular immunity in a mouse model of TC-1 graft tumor. Int. J Nanomed. 2017, 12, 6813-6825. [CrossRef]

102. Peer, D.; Karp, J.M.; Hong, S.; Farokhzad, O.C.; Margalit, R.; Langer, R. Nanocarriers as an emerging platform for cancer therapy. Nat. Nanotechnol. 2007, 2, 751. [CrossRef] [PubMed]

103. Ernsting, M.J.; Murakami, M.; Roy, A.; Li, S.D. Factors controlling the pharmacokinetics, biodistribution and intratumoral penetration of nanoparticles. J. Control. Release Soc. 2013, 172, 782-794. [CrossRef] [PubMed] 
104. Tahmasbi Rad, A.; Chen, C.W.; Aresh, W.; Xia, Y.; Lai, P.S.; Nieh, M.P. Combinational Effects of Active Targeting, Shape, and Enhanced Permeability and Retention for Cancer Theranostic Nanocarriers. ACS Appl. Mater. Interfaces 2019, 11, 10505-10519. [CrossRef] [PubMed]

105. Vipul, G.; Sunghyun, K.; Sang-Hyun, K.; Jung Joon, M.; Choy, H.E.; Chang, K.S.; Sangyong, J. Bioengineered bacterial outer membrane vesicles as cell-specific drug-delivery vehicles for cancer therapy. ACS Nano 2014, 8, 1525-1537.

106. Coley, W.B. The treatment of malignant tumors by repeated inoculations of erysipelas. With a report of ten original cases. 1893. Clin. Orthop. Relat. Res. 1991, 105, 3-11.

107. Wallecha, A.; Malinina, I.; Ramos, K.; Singh, R. Abstract 5241: Development of a single Listeria monocytogene-based vaccine simultaneously targeting two antigens. Cancer Res. 2012, 72, 5241.

108. Wang, S.; Kong, Q.; Iii, R.C. New technologies in developing recombinant attenuated Salmonella vaccine vectors. Microb. Pathog. 2013, 58, 17-28. [CrossRef] [PubMed]

109. Bertrand, T.; Xavier, C.; Yan, W.; Benoit, P.; Audrey, L.G.L. Live-attenuated bacteria as a cancer vaccine vector. Expert Rev. Vaccines 2013, 12, 1139-1154.

110. Nicholas, A.; Jeon, H.; Selasi, G.N.; Na, S.H.; Kwon, H.I.; Kim, Y.J.; Choi, C.W.; Kim, S.I.; Lee, J.C. Clostridium difficile-derived membrane vesicles induce the expression of pro-inflammatory cytokine genes and cytotoxicity in colonic epithelial cells in vitro. Microb. Pathog. 2017, 107, 6-11. [CrossRef]

111. Kim, J.H.; Jeun, E.J.; Hong, C.P.; Kim, S.H.; Jang, M.S.; Lee, E.J.; Moon, S.J.; Yun, C.H.; Im, S.H.; Jeong, S.G.; et al. Extracellular vesicle-derived protein from Bifidobacterium longum alleviates food allergy through mast cell suppression. J. Allergy Clin. Immunol. 2016, 137, 507-516.e508. [CrossRef]

112. Kim, O.Y.; Park, H.T.; Nth, D.; Choi, S.J.; Lee, J.; Kim, J.H.; Lee, S.W.; Gho, Y.S. Bacterial outer membrane vesicles suppress tumor by interferon- $\gamma$-mediated antitumor response. Nat. Commun. 2017, 8, 626. [CrossRef] [PubMed]

113. Loeffler, M.; Le'Negrate, G.; Krajewska, M.; Reed, J.C. IL-18-producing Salmonella inhibit tumor growth. Cancer Gene Ther. 2008, 15, 787. [CrossRef] [PubMed]

114. Markus, L.; Gaelle, L.N.; Maryla, K.; Reed, J.C. Attenuated Salmonella engineered to produce human cytokine LIGHT inhibit tumor growth. Proc. Natl. Acad. Sci. USA 2007, 104, 12879-12883.

115. Loeffler, M.; Le'Negrate, G.; Krajewska, M.; Reed, J.C. Salmonella typhimurium engineered to produce CCL21 inhibit tumor growth. Cancer Immunol. Immunother. 2009, 58, 769-775. [CrossRef] [PubMed]

116. Ganai, S.; Arenas, R.B.; Forbes, N.S. Tumour-targeted delivery of TRAIL using Salmonella typhimurium enhances breast cancer survival in mice. Br. J. Cancer 2009, 101, 1683. [CrossRef]

117. Loeffler, M.; Le'Negrate, G.M.; Reed, J. Inhibition of tumor growth using salmonella expressing Fas ligand. J. Natl. Cancer. Inst. 2008, 100, 1113-1116. [CrossRef] [PubMed]

118. Bereta, M.; Hayhurst, A.; Gajda, M.; Chorobik, P.; Targosz, M.; Marcinkiewicz, J.; Kaufman, H.L. Improving tumor targeting and therapeutic potential of Salmonella VNP20009 by displaying cell surface CEA-specific antibodies. Vaccine 2007, 25, 4183-4192. [CrossRef]

119. Quintero, D.; Carrafa, J.; Vincent, L.; Bermudes, D. EGFR-targeted chimeras of Pseudomonas ToxA released into the extracellular milieu by attenuated Salmonella selectively kill tumor cells. Biotechnol. Bioeng. 2016, 113, 2698-2711. [CrossRef]

120. King, I.; Bermudes, D.; Lin, S.; Belcourt, M.; Pike, J.; Troy, K.; Le, T.; Ittensohn, M.; Mao, J.; Lang, W. Tumor-targeted salmonella expressing Cytosine deaminase as an anticancer agent. Hum. Gene Ther. 2002, 13, 1225-1233. [CrossRef]

121. Zhao, C.; He, J.; Cheng, H.; Zhu, Z.; Xu, H. Enhanced therapeutic effect of an antiangiogenesis peptide on lung cancer in vivo combined with salmonella VNP20009 carrying a Sox2 shRNA construct. J. Exp. Clin. Cancer Res. 2016, 35, 107. [CrossRef]

122. Blache, C.A.; Manuel, E.R.; Kaltcheva, T.I.; Wong, A.N.; Ellenhorn, J.D.I.; Blazar, B.R.; Diamond, D.J. Systemic delivery of Salmonella typhimurium transformed with IDO shRNA enhances intratumoral vector colonization and suppresses tumor growth. Cancer Res. 2011, 72, 6447-6456. [CrossRef] [PubMed]

123. Sorenson, B.S.; Banton, K.L.; Frykman, N.L.; Leonard, A.S.; Saltzman, D.A. Attenuated Salmonella typhimurium with IL-2 Gene Reduces Pulmonary Metastases in Murine Osteosarcoma. Clin. Orthop. Relat. Res. 2008, 466, 1285-1291. [CrossRef] [PubMed] 
124. Yoon, W.; Park, Y.C.; Kim, J.; Yang, S.C.; Byeon, J.H.; Min, S.H.; Park, S.; Yoo, Y.; Yong, K.P.; Kim, B.M. Application of genetically engineered Salmonella typhimurium for interferon-gamma-induced therapy against melanoma. Eur. J. Cancer 2017, 70, 48-61. [CrossRef] [PubMed]

125. Nguyen, V.H.; Hyung-Seok, K.; Jung-Min, H.; Yeongjin, H.; Choy, H.E.; Jung-Joon, M. Genetically engineered Salmonella typhimurium as an imageable therapeutic probe for cancer. Cancer Res. 2010, 70, 18-23. [CrossRef] [PubMed]

126. Jae-Ho, J.; Kwangsoo, K.; Daejin, L.; Kwangjoon, J.; Yeongjin, H.; Nguyen, V.H.; Tae-Hyoung, K.; Sangryeol, R.; Jeong, A.L.; Jae, K., II. Anti-tumoral effect of the mitochondrial target domain of Noxa delivered by an engineered Salmonella typhimurium. PLoS ONE 2014, 9, e80050.

127. Zheng, J.H.; Nguyen, V.H.; Jiang, S.N.; Park, S.H.; Tan, W.; Hong, S.H.; Shin, M.G.; Chung, I.J.; Hong, Y.; Bom, H.S. Two-step enhanced cancer immunotherapy with engineered Salmonella typhimurium secreting heterologous flagellin. Sci. Transl. Med. 2017, 9, eaak9537. [CrossRef] [PubMed]

128. Massa, P.E.; Aida, P.; Ana, M.; Ario, D.M.; Maria, R. Salmonella engineered to express CD20-targeting antibodies and a drug-converting enzyme can eradicate human lymphomas. Blood 2013, 122, 705-714. [CrossRef]

129. Yoon, W.; Ji, H.C.; Kim, S.; Yong, K.P. Engineered Salmonella typhimurium expressing E7 fusion protein, derived from human papillomavirus, inhibits tumor growth in cervical tumor-bearing mice. Biotechnol. Lett. 2014, 36, 349-356. [CrossRef]

130. Yuhua, L.; Kunyuan, G.; Hui, C.; Yongmei, X.; Chaoyang, S.; Xun, T.; Daming, R. Oral cytokine gene therapy against murine tumor using attenuated Salmonella typhimurium. Int. J. Cancer J. Int. Du Cancer 2010, 94, 438-443. [CrossRef]

131. Caroline, A.; Fernanda, S.; Mark, S.; Piero, M.; Marcelo, F.; Miguel Angel, M.; Jose Alejandro, C. Live attenuated Salmonella as a vector for oral cytokine gene therapy in melanoma. J. Gene Med. 2010, 9, 416-423.

132. Cao, H.D.; Yang, Y.X.; Lin, L.; Liu, S.N.; Wang, P.L.; Tao, X.H.; Wang, L.J.; Xiang, T.X. Attenuated Salmonella typhimurium carrying TRAIL and VP3 genes inhibits the growth of gastric cancer cells in vitro and in vivo. Tumori 2010, 96, 296-303. [CrossRef] [PubMed]

133. Shi, L.; Yu, B.; Cai, C.H.; Huang, W.; Zheng, B.J.; Smith, D.K.; Huang, J.D. Combined prokaryotic-eukaryotic delivery and expression of therapeutic factors through a primed autocatalytic positive-feedback loop. $J$. Control. Release 2016, 222, 130-140. [CrossRef] [PubMed]

134. Jianxin, Y.; Ling, L.; Yuanting, Z.; Xueguang, Z.; Daming, R.; Weichang, C. Recombinant Salmonella-based $4-1 B B L$ vaccine enhances $\mathrm{T}$ cell immunity and inhibits the development of colorectal cancer in rats: In vivo effects of vaccine containing 4-1BBL. J. Biomed. Sci. 2013, 20, 8.

135. Elisa, B.; Rocio, S.; Nicole, H.; Oliver, H.; Alexander, S.; Tahir, D.; Stephan, L.; Zenclussen, A.C.; Holger, C.; Lode, H.N. Salmonella SL7207 application is the most effective DNA vaccine delivery method for successful tumor eradication in a murine model for neuroblastoma. Cancer Lett. 2013, 331, 167-173.

136. Shu, G.Z.; Chen, Y.; Zhi, P.W. Orally Administered DNA Vaccine Delivery by Attenuated Salmonellatyphimurium Targeting Fetal Liver Kinase 1 Inhibits Murine Lewis LungCarcinoma Growth and Metastasis. Biol. Pharm. Bull. 2010, 33, 174-182.

137. Ahmad, S.; Casey, G.; Cronin, M.; Rajendran, S.; Sweeney, P.; Tangney, M.; O'Sullivan, G.C. Induction of Effective Antitumor Response After Mucosal Bacterial Vector Mediated DNA Vaccination With Endogenous Prostate Cancer Specific Antigen. J. Urol. 2011, 186, 687-693. [CrossRef]

138. Zhou, J.H.; Chen, Y.C.; Li, T. Tumor-targeting Salmonella typhimurium, a natural tool for activation of prodrug $6 \mathrm{MePdR}$ and their combination therapy in murine melanoma model. Appl. Microbiol. Biotechnol. 2013, 97, 4393-4401.

139. Nan, Y.; Zhu, X.; Chen, L.; Li, S.; Ren, D. Oral administration of attenuated S. typhimurium carrying shRNA-expressing vectors as a cancer therapeutic. Cancer Biol. Ther. 2008, 7, 145-151.

140. Kim, K.; Jeong, J.H.; Lim, D.; Hong, Y.; Lim, H.J.; Kim, G.J.; Shin, S.R.; Lee, J.J.; Yun, M.; Harris, R.A. L-Asparaginase delivered by Salmonella typhimurium suppresses solid tumors. Mol. Ther. Oncol. 2015, 2, 15007. [CrossRef]

141. Park, S.H.; Zheng, J.H.; Nguyen, V.H.; Jiang, S.N.; Kim, D.Y.; Szardenings, M.; Min, J.H.; Hong, Y.; Choy, H.E.; Min, J.J. RGD Peptide Cell-Surface Display Enhances the Targeting and Therapeutic Efficacy of AttenuatedSalmonella-mediated Cancer Therapy. Theranostics 2016, 6, 1672-1682. [CrossRef] 
142. Shi, L.; Yu, B.; Cai, C.H.; Huang, J.D. Angiogenic inhibitors delivered by the type III secretion system of tumor-targeting Salmonella typhimurium safely shrink tumors in mice. AMB Express 2016, 6, 56. [CrossRef] [PubMed]

143. Jia, H.; Li, Y.; Zhao, T.; Li, X.; Hu, J.; Yin, D.; Guo, B.; Kopecko, D.J.; Zhao, X.; Zhang, L. Antitumor effects of Stat3-siRNA and endostatin combined therapies, delivered by attenuated Salmonella, on orthotopically implanted hepatocarcinoma. Cancer Immunol. Immunother. 2012, 61, 1977-1987. [CrossRef] [PubMed]

144. Guosheng, X.; Husseiny, M.I.; Liping, S.; Anat, E.E.; Shackleford, G.M.; Seeger, R.C.; Daniela, J.C.; Michael, H.; Metelitsa, L.S. Novel cancer vaccine based on genes of Salmonella pathogenicity island 2. Int. J. Cancer 2010, 126, 2622-2634.

145. Al-Ramadi, B.K.; Fernandez-Cabezudo, M.J.; El-Hasasna, H.; Al-Salam, S.; Bashir, G.; Chouaib, S. Potent anti-tumor activity of systemically-administered IL2-expressing Salmonella correlates with decreased angiogenesis and enhanced tumor apoptosis. Clin. Immunol. 2009, 130, 89-97. [CrossRef] [PubMed]

146. Lewēn, S.; Zhou, H.; Hu, H.; Cheng, T.; Markowitz, D.; Reisfeld, R.A.; Xiang, R.; Luo, Y. A Legumain-based minigene vaccine targets the tumor stroma and suppresses breast cancer growth and angiogenesis. Cancer Immunol. Immunother. 2008, 57, 507-515. [CrossRef] [PubMed]

147. Roider, E.; Jellbauer, S.; Köhn, B.; Berchtold, C.; Partilla, M.; Busch, D.H.; Rüssmann, H.; Panthel, K. Invasion and destruction of a murine fibrosarcoma by Salmonella -induced effector CD8 T cells as a therapeutic intervention against cancer. Cancer Immunol. Immunother. 2011, 60, 371-380. [CrossRef] [PubMed]

148. Shahabi, V.; Seavey, M.M.; Maciag, P.C.; Rivera, S.; Wallecha, A. Development of a live and highly attenuated Listeria monocytogenes-based vaccine for the treatment of Her2/neu-overexpressing cancers in human. Cancer Gene Ther. 2011, 18, 53. [CrossRef]

149. Seavey, M.; Maciag, P.R.N.; Sewell, D.; Paterson, Y. An anti-vascular endothelial growth factor receptor $2 /$ fetal liver kinase-1 Listeria monocytogenes anti-angiogenesis cancer vaccine for the treatment of primary and metastatic Her-2/neu+ breast tumors in a mouse model. J. Immunol. 2009, 182, 5537-5546. [CrossRef]

150. Shahabi, V.; Reyes-Reyes, M.; Wallecha, A.; Rivera, S.; Paterson, Y.; Maciag, P. Development of a Listeria monocytogenes based vaccine against prostate cancer. Cancer Immunol. Immunother. 2008, 57, 1301. [CrossRef]

151. Le, D.T.; Andrea, W.G.; Vincent, P.; Greten, T.F.; Todd, C.; Gregory, S.; Michael, M.; Herbert, Z.; Deirdre, C.; Fine, R.L. Safety and survival with GVAX pancreas prime and Listeria Monocytogenes-expressing mesothelin (CRS-207) boost vaccines for metastatic pancreatic cancer. J. Clin. Oncol. 2016, 33, 1325-1333. [CrossRef]

152. Crittenden, M.; Bahjat, K.S.; Li, R.; Gore, P.; Fountain, C.; Hanson, B.; Skoble, J.; Lauer, P.; Murphy, A.L.; Dubensky, T. Phase I study of safety and immunogenicity of ADU-623, a live-attenuated listeria monocytogenes vaccine ( $\triangle$ actA/ $\Delta$ inlB) expressing EGFRVIII and NY-ESO-1, in patients with who grade III/IV astrocytomas. J. Immunother. Cancer 2015, 3, 1-2. [CrossRef]

153. Yang, J.; Zhuo, D.C.; Xudong, Z.; Chen, B. Attenuated Listeria monocytogenes as a cancer vaccine vector for the delivery of CD24, a biomarker for hepatic cancer stem cells. Cell. Mol. Immunol. 2014, 11, 184. [CrossRef] [PubMed]

154. Lemmon, M.J.; Van Zijl, P.; Fox, M.E.; Mauchline, M.L.; Giaccia, A.J.; Minton, N.P.; Brown, J.M. Anaerobic bacteria as a gene delivery system that is controlled by the tumor microenvironment. Gene Ther. 1997, 4, 791. [CrossRef] [PubMed]

155. Theys, J.; Landuyt, A.W.; Nuyts, S.; Van, M.L.; Lambin, P.; Anné, J. Clostridium as a tumor-specific delivery system of therapeutic proteins. Cancer Detect. Prev. 2001, 25, 548-557. [PubMed]

156. Yazawa, K.; Fujimori, M.J.; Kano, Y.; Taniguchi, S. Bifidobacterium longum as a delivery system for cancer gene therapy: Selective localization and growth in hypoxic tumors. Cancer Gene Ther. 2000, 7, 269-274. [CrossRef] [PubMed]

157. Kitagawa, K.; Oda, T.; Saito, H.; Araki, A.; Gonoi, R.; Shigemura, K.; Hashii, Y.; Katayama, T.; Fujisawa, M.; Shirakawa, T. Development of oral cancer vaccine using recombinant Bifidobacterium displaying Wilms' tumor 1 protein. Cancer Immunol. Immunother. 2017, 66, 787-798. [CrossRef]

158. Shirakawa, T.; Kitagawa, K. Antitumor effect of oral cancer vaccine with Bifidobacterium delivering WT1 protein to gut immune system is superior to WT1 peptide vaccine. Hum. Vaccin. Immunother. 2018, 14, 159-162. [CrossRef]

159. Hu, B.; Kou, L.; Li, C.; Zhu, L.P.; Fan, Y.R.; Wu, Z.W.; Wang, J.J.; Xu, G.X. Bifidobacterium longum as a delivery system of TRAIL and endostatin cooperates with chemotherapeutic drugs to inhibit hypoxic tumor growth. Cancer Gene Ther. 2009, 16, 655. [CrossRef] 
160. Xi, L.; Geng-Feng, F.; Yan-Rong, F.; Wen-Hua, L.; Xin-Juan, L.; Jian-Jun, W.; Gen-Xing, X. Bifidobacterium adolescentis as a delivery system of endostatin for cancer gene therapy: Selective inhibitor of angiogenesis and hypoxic tumor growth. Cancer Gene Ther. 2003, 10, 105.

161. Zhu, H.; Li, Z.; Mao, S.; Ma, B.; Zhou, S.; Deng, L.; Liu, T.; Cui, D.; Zhao, Y.; He, J. Antitumor effect of sFlt-1 gene therapy system mediated by Bifidobacterium Infantis on Lewis lung cancer in mice. Cancer Gene Ther. 2011, 18, 884-896. [CrossRef]

162. Derouazi, M.; Yan, W.; Marlu, R.; Epaulard, O.; Mayol, J.F.; Pasqual, N.; Gouellec, A.L.; Polack, B.; Toussaint, B. Optimal epitope composition after antigen screening using a live bacterial delivery vector. Bioeng. Bugs 2010, 1, 51-60. [CrossRef] [PubMed]

163. Wang, Y.; Gouëllec, A.L.; Chaker, H.; Asrih, H.; Polack, B.; Toussaint, B. Optimization of antitumor immunotherapy mediated by type III secretion system-based live attenuated bacterial vectors. J. Immunother. 2012, 35, 223. [CrossRef] [PubMed]

164. St Jean, A.T.; Swofford, C.A.; Panteli, J.T.; Brentzel, Z.J.; Forbes, N.S. Bacterial delivery of Staphylococcus aureus $\alpha$-hemolysin causes regression and necrosis in murine tumors. Mol. Ther. 2014, 22, 1266-1274. [CrossRef] [PubMed]

(C) 2019 by the authors. Licensee MDPI, Basel, Switzerland. This article is an open access article distributed under the terms and conditions of the Creative Commons Attribution (CC BY) license (http://creativecommons.org/licenses/by/4.0/). 